Published in final edited form as:

Cochrane Database Syst Rev. ; 6: CD004567. doi:10.1002/14651858.CD004567.pub2.

\title{
Antioxidant vitamin supplementation for preventing and slowing the progression of age-related cataract
}

\author{
Milan C Mathew ${ }^{1}$, Ann-Margret Ervin ${ }^{2}$, Jeremiah Tao $^{3}$, and Richard M Davis ${ }^{4}$ \\ ${ }^{1}$ MetroWest Medical Center, Framingham, Massachusetts, USA \\ ${ }^{2}$ Department of Epidemiology, Johns Hopkins Bloomberg School of Public Health, Baltimore, \\ Maryland, USA \\ ${ }^{3}$ Ophthalmology, University of California, Irvine, Irvine, California, USA
}

\author{
Copyright (C 2012 The Cochrane Collaboration. Published by John Wiley \& Sons, Ltd. \\ milan@milanmathew.com. \\ CONTRIBUTIONS OF AUTHORS \\ Conceiving the review: $\mathrm{SN}, \mathrm{RD}$ \\ Writing the protocol: SN, JT, RD, MM \\ Designing the review: MM, JT, RD \\ Co-ordinating the review: MM, AE \\ Data collection for the review

$$
\begin{aligned}
& \text { Designing search strategies: CEVG Trials Search Co-ordinator } \\
& \text { Undertaking searches: CEVG Trials Search Co-ordinator } \\
& \text { Screening search results: MM, AE, JT } \\
& \text { Organizing retrieval of papers: MM, AE }
\end{aligned}
$$ \\ - $\quad$ Screening retrieved papers against inclusion criteria: MM, AE, JT \\ - $\quad$ Appraising quality of papers: MM, AE, JT \\ - $\quad$ Extracting data from papers: MM, AE, JT \\ - Writing to authors of papers for additional information: MM \\ - $\quad$ Providing additional data about papers: MM \\ - $\quad$ Obtaining and screening data on unpublished studies: MM
}

Contact address: Milan C Mathew, MetroWest Medical Center, 115 Lincoln Street, Framingham, Massachusetts, 01702, USA.

Data management for the review

- $\quad$ Entering data into RevMan 5: MM, AE

- $\quad$ Analysis of data: MM, AE

Interpretation of data

- $\quad$ Providing a methodological perspective: MM, AE, JT, RD

- $\quad$ Providing a clinical perspective: MM, JT, RD

Writing the review: MM, AE, JT, RD

Guarantor for review: MM

DECLARATIONS OF INTEREST

None known.

DIFFERENCES BETWEEN PROTOCOL AND REVIEW

Cochrane methodology regarding assessments of the risk of bias in included studies has been modified and the review authors updated the 'Assessment of risk of bias in included studies' section of the methods to reflect updated methodological considerations. 
${ }^{4}$ Department of Ophthalmology, University of North Carolina, Chapel Hill, North Carolina, USA

\section{Abstract}

Background-Age-related cataract is a major cause of visual impairment in the elderly. Oxidative stress has been implicated in its formation and progression. Antioxidant vitamin supplementation has been investigated in this context.

Objectives-To assess the effectiveness of antioxidant vitamin supplementation in preventing and slowing the progression of age-related cataract.

Search methods-We searched CENTRAL (which contains the Cochrane Eyes and Vision Group Trials Register) (The Cochrane Library 2012, Issue 2), MEDLINE (January 1950 to March 2012), EMBASE (January 1980 to March 2012), Latin American and Caribbean Literature on Health Sciences (LILACS) (January 1982 to March 2012), Open Grey (System for Information on Grey Literature in Europe) (www.opengrey.eu/), the metaRegister of Controlled Trials ( $m$ RCT) (www.controlled-trials.com), ClinicalTrials.gov (www.clinicaltrials.gov) and the WHO International Clinical Trials Registry Platform (ICTRP) (www.who.int/ictrp/search/en). There were no date or language restrictions in the electronic searches for trials. The electronic databases were last searched on 2 March 2012. We also checked the reference lists of included studies and ongoing trials and contacted investigators to identify eligible randomized trials.

Selection criteria-We included only randomized controlled trials in which supplementation with one or more antioxidant vitamins (beta-carotene, vitamin C and vitamin E) in any form, dosage or combination for at least one year was compared to another antioxidant vitamin or to placebo.

Data collection and analysis-Two authors extracted data and assessed trial quality independently. We pooled results for the primary outcomes, i.e., incidence of cataract and incidence of cataract extraction. We did not pool results of the secondary outcomes - progression of cataract and loss of visual acuity, because of differences in definitions of outcomes and data presentation. We pooled results by type of cataract when data were available. We did not perform a sensitivity analysis.

Main results-Nine trials involving 117,272 individuals of age 35 years or older are included in this review. The trials were conducted in Australia, Finland, India, Italy, the United Kingdom and the United States, with duration of follow-up ranging from 2.1 to 12 years. The doses of antioxidant vitamins were higher than the recommended daily allowance. There was no evidence of effect of antioxidant vitamin supplementation in reducing the risk of cataract, cataract extraction, progression of cataract or in slowing the loss of visual acuity. In the pooled analyses, there was no evidence of effect of beta-carotene supplementation in reducing the risk of cataract (two trials) (relative risk (RR) $0.99,95 \%$ confidence interval (CI) 0.91 to $1.08 ; \mathrm{n}=57,703$ ) or in reducing the risk of cataract extraction (three trials) (RR 1.00, 95\% CI 0.91 to $1.10 ; \mathrm{n}=86,836$ ) or of vitamin E supplementation in reducing the risk of cataract (three trials) (RR 0.97, 95\% CI 0.91 to $1.04 ; \mathrm{n}=50,059$ ) or of cataract extraction (five trials) (RR 0.98, 95\% CI 0.91 to $1.05 ; \mathrm{n}=$ 83,956 ). The proportion of participants developing hypercarotenodermia (yellowing of skin) while on beta-carotene ranged from $7.4 \%$ to $15.8 \%$. 
Authors' conclusions-There is no evidence from RCTs that supplementation with antioxidant vitamins (beta-carotene, vitamin $\mathrm{C}$ or vitamin $\mathrm{E}$ ) prevents or slows the progression of age-related cataract. We do not recommend any further studies to examine the role of antioxidant vitamins beta-carotene, vitamin $\mathrm{C}$ and vitamin $\mathrm{E}$ in preventing or slowing the progression of agerelated cataract. Costs and adverse effects should be weighed carefully with unproven benefits before recommending their intake above recommended daily allowances.

\section{PLAIN LANGUAGE SUMMARY}

\section{Antioxidant vitamins for preventing and slowing the progression of age-related cataract}

A cataract occurs when the normally clear lens in the eye becomes cloudy. Cataracts are the leading cause of correctable reduced vision worldwide. Most cataracts develop slowly with normal aging. However, cataracts also may be related to genetic diseases and medical conditions such as diabetes. Other factors such as poor nutrition, sun damage, radiation, corticosteroids, smoking, alcohol, eye trauma or other eye surgery may influence cataract formation.

Mild or early cataracts may not impair vision. In some cataracts, new eye-glass prescriptions, brighter lighting or magnifying lenses may overcome the vision losses. When these interventions fail to improve poor vision due to cataracts, surgical removal (extraction) is the generally accepted effective treatment. However, cataract surgery is associated with some risks. The estimated annual costs for outpatient, inpatient and prescription drug services related to the treatment of cataract is USD 6.8 billion.

Antioxidant vitamin supplementation has been studied as a means to prevent the formation or to slow the progression of cataract. Results from observational studies have been inconsistent.

The review authors searched for randomized controlled trials in which supplementation with the antioxidant vitamins beta-carotene (provitamin A), vitamin C and vitamin $\mathrm{E}$ was compared to inactive placebo or no supplement. Nine trials involving 117,272 adults of age 35 years or older were included in this review. The trials were conducted in Australia, Finland, India, Italy, the United Kingdom and the United States and were of high methodological quality. The doses of antioxidants given in each trial were higher than the recommended daily allowances. The trials provided no evidence of effect of the antioxidant vitamins beta-carotene, vitamin $\mathrm{E}$ and vitamin $\mathrm{C}$ given alone or in combination on the incidence of cataract, its extraction or progression and on the loss of visual acuity. Some participants (7\% to $16 \%$ ) on beta-carotene developed yellowing of the skin (hypercarotenodermia).

\section{BACKGROUND}

\section{Description of the condition}

Introduction-Cataract is the opacification of the normally transparent lens in the eye. Cataracts might be congenital or hereditary, associated with certain risk factors and systemic diseases, or caused by toxins and drugs or physical trauma. 
Most cataracts develop slowly as a consequence of aging. The pathogenesis of age-related cataract is multifactorial and not completely understood. Important risk factors in addition to age include diabetes mellitus, exposure to ultraviolet radiation, use of corticosteroids and recreational drugs such as nicotine and alcohol. The formation of cataract is accelerated in ocular trauma, vitreoretinal surgery, uveitis and diabetes mellitus. Oxidation reactions in the lens, both as a consequence to normal aging and those triggered by UV radiation, are believed to be potent etiological factors in the development of cataract (Abraham 2006; West 1995).

The earliest opacities may appear anywhere within the body of the lens; the processes that culminate in poor vision vary depending upon the site of initiation. Thus, age-related cataract is classified into three major types: nuclear, cortical and posterior subcapsular. Among these, cigarette smoking has been linked with nuclear cataract whereas corticosteroid use and trauma have been linked with posterior subcapsular cataract (Wevill 2008).

Epidemiology-Age-related cataract is the leading cause of blindness in the world. It accounts for 17.7 million (47.8\%) of the total 37 million cases worldwide. It is even more significant as a cause of low vision and is the leading cause of low vision in all the World Health Organization sub-regions (GDVI 2004). In the United States, an estimated 20.5 million (17.2\%) people older than 40 years have cataract in one or both eyes, with the prevalence expected to rise by 50\% to 30.1 million in 2020 (Congdon 2004).

Women have a higher risk of being visually impaired than men. The worldwide prevalence ratio of female to male visual impairment ranges from 1.5 to 2.2 (GDVI 2004). In the United States, women have higher age-adjusted prevalence of cataract than men (Congdon 2004). The odds of cataract were $75 \%$ (odds ratio (OR) 1.75, 95\% confidence interval (CI) 1.18 to 2.56 ) and $35 \%$ (OR 1.35, 95\% CI 1.23 to 1.49) higher among black and white women respectively when compared to men (Congdon 2004). The prevalence increases with age and the overall global burden is expected to rise with increases in life expectancy.

Costs-Recent data on the costs related to management of cataract worldwide are unavailable. In the United States, healthcare costs for individuals over age 65 are partially covered by Medicare. Cataract surgery, IOL implantation, and other cataract-related costs amount to about $60 \%$ of all Medicare expenditures related to vision (Ellwein 2002). It is estimated that the direct annual medical costs for outpatient, inpatient and prescription drug services related to the treatment of cataract total USD 6.8 billion (PBA 2008).

Interventions for cataract-The symptoms of early cataract can possibly be improved with the use of new eyeglasses, brighter lighting, anti-glare glasses or magnifying lenses. However, surgical extraction is the only effective treatment for cataract (Leyland 2006; Riaz 2006). There are no medications, eye drops, exercises or glasses that have been proven to be effective in preventing the formation or slowing the progression of cataract in the otherwise healthy aging adult eye. 
Description of the intervention-Supplementation with vitamins with antioxidant properties such as beta-carotene and vitamins $\mathrm{C}$ and $\mathrm{E}$ have been proposed as candidate interventions to prevent or slow progression of cataract. Beta-carotene is a red-orange fatsoluble compound abundant in fruits such as mangoes, papayas, carrots and yams and in green leafy vegetables such as spinach, kale and leaves of sweet potato and sweet gourd. It is a provitamin converted by the body to active vitamin A which has antioxidant properties. Vitamin A plays an important role in vision and is also needed for bone development, testicular and ovarian function, embryonic development and maintenance of mucosal and epithelial surfaces. The recommended dietary allowance (RDA) for adults has been established by the U.S. Institute of Medicine of the National Academy of Sciences. There are no RDA for beta-carotene. The RDA for vitamin A is 900 micrograms retinol (3000 International Units (IU)) for adult males and 700 micrograms retinol (2300 IU) for adult females. One microgram of retinol is equivalent to one Retinol Activity Equivalents (RAE). One RAE is equivalent to 2 micrograms all-trans-beta-carotene as a supplement or 12 micrograms of all-trans-beta-carotene in the diet. Deficiency of vitamin A can cause night blindness, xerophthalmia (dry eyes), dermatological problems and impairment of immune response.

Vitamin $\mathrm{C}$ is a water-soluble compound present in milk and animal products such as liver and fish; vitamin $\mathrm{C}$ is abundant in vegetables and fruits, especially citrus fruits such as oranges. It is important in the synthesis of collagen and carnitine and for neurotransmitter and cholesterol metabolism; it has antioxidant properties. The RDA for vitamin $\mathrm{C}$ is $90 \mathrm{mg}$ for adult males and $75 \mathrm{mg}$ for adult females. Deficiency of vitamin C causes scurvy.

Vitamin $\mathrm{E}$ is a fat-soluble compound found in a variety of foods including oils, meat, eggs and leafy vegetables. Vitamin $\mathrm{E}$ has antioxidant properties and works as a free radical scavenger, protecting polyunsaturated fatty acids (PUFA), a major structural component of the cell membranes, from peroxidation. The RDA for vitamin E is $15 \mathrm{mg}$ (22.4 IU) for adolescents and adults. Deficiency of vitamin E can cause neuromuscular disorders, lysis of red blood cells and impairment of immune response.

How the intervention might work-Oxidation of lens proteins and mitochondrial function are key factors in cataract pathogenesis (Wevill 2008). Beta-carotene is known to be an effective antioxidant at low partial pressures of oxygen, as exists in the lens (Burton 1984). Vitamin C is located in the aqueous compartments of lens membranes where it may function as an antioxidant and protect enzymes in the lens from photo-oxidative destruction (Blondin 1986). Vitamin $\mathrm{E}$ is lipid soluble and concentrated in the lens fibers and membranes and may inhibit cataract formation by reducing photo-peroxidation of lens lipids and by stabilizing lens cell membranes (Karslioglu 2004; Libondi 1985; Ohta 1996; Varma 1982).

Why it is important to do this review-Laboratory and epidemiologic evidence linking oxidative stress to cataract formation have led investigators to assess the role of antioxidant intake in the development of age-related cataract. Several observational studies have noted protective associations for various antioxidants. However, in totality, the evidence from the large number of observational studies that have examined this association (Brown 1999; 
Chasan-Taber 1999; Cumming 2000; Hankinson 1992; IACS 1991; Jacques 1988; Jacques 1991; Jacques 1997; Jacques 2001; Knekt 1992; Kuzniarz 2001; Leske 1991; Leske 1995; Leske 1997; Leske 1998; Lyle 1999; Mares-Perlman 1994; Mares-Perlman 1995; MaresPerlman 2000; McCarty 1999; Milton 2006; Mohan 1989; Nadalin 1999; Robertson 1989; Robertson 1991; Rouhiainen 1996; Seddon 1994; Tavani 1996; Taylor 2002; Vitale 1993; Yoshida 2007) is inconsistent. The possibility of biases and unadjusted confounding in these observational studies provided the rationale for randomized controlled trials to examine this association. However, there are no known systematic reviews that have examined the role of antioxidant vitamin supplementation in preventing or slowing the progression of age-related cataract.

\section{OBJECTIVES}

To assess the effectiveness of antioxidant vitamin supplementation, specifically betacarotene, vitamin $\mathrm{C}$ and vitamin $\mathrm{E}$, in preventing and slowing the progression of age-related cataract.

\section{METHODS}

Criteria for considering studies for this review

Types of studies-We included randomized controlled trials with a minimum follow-up of one year.

Types of participants-We included trials of participants irrespective of demographic characteristics or co-morbidities.

Types of interventions-We included randomized controlled trials in which supplementation with one or more antioxidant vitamins, specifically beta-carotene, vitamin $\mathrm{C}$ and vitamin $\mathrm{E}$ in any form, dosage or combination, for at least one year was compared to another antioxidant vitamin, to placebo or to no supplementation.

\section{Types of outcome measures}

\section{Primary outcomes}

1. Incidence of cataract as defined by the included studies

2. Incidence of cataract extraction: defined as surgery to remove a visually significant lens opacity. The determination of visually significant was as defined by the included studies

\section{Secondary outcomes}

1. Progression of cataract: we used any well-defined measure of progression depending on the way authors presented trial data.

2. Loss of vision: we used any well-defined measure of visual acuity depending on the way authors presented trial data. 
Adverse effects: We report the adverse effects of beta-carotene and vitamin E supplementation.

\section{Search methods for identification of studies}

Electronic searches-We searched the Cochrane Central Register of Controlled Trials (CENTRAL) 2012, Issue 2, part of The Cochrane Library. www.thecochranelibrary.com (accessed 2 March 2012), MEDLINE (January 1950 to March 2012), EMBASE (January 1980 to March 2012), Latin American and Caribbean Literature on Health Sciences (LILACS) (January 1982 to March 2012), Open Grey (System for Information on Grey Literature in Europe) (www.opengrey.eu/), the metaRegister of Controlled Trials ( $m \mathrm{RCT}$ ) (www.controlled-trials.com), ClinicalTrials.gov (www.clinicaltrials.gov) and the WHO International Clinical Trials Registry Platform (ICTRP) (www.who.int/ictrp/search/en). There were no language or date restrictions in the search for trials. The electronic databases were last searched on 2 March 2012. See: Appendices for details of search strategies for CENTRAL (Appendix 1), MEDLINE (Appendix 2), EMBASE (Appendix 3), LILACS (Appendix 4), OpenGrey (Appendix 5), $m$ RCT (Appendix 6), ClinicalTrials.gov (Appendix 7) and the ICTRP (Appendix 8).

Searching other resources-We searched the reference lists of included studies and ongoing trials to identify additional trials. We used the Science Citation Index to identify trials that referenced these trials. We contacted the investigators of the included trials for information on additional and unreported trials.

\section{Data collection and analysis}

Selection of studies-We independently screened the titles and abstracts obtained by the searches. We obtained and assessed the full-text copies of reports from probable or definitely relevant trials as per the 'Criteria for considering studies for this review' section. We assessed all articles that met the inclusion criteria for methodological quality.

Data extraction and management-Two review authors independently extracted data using a form developed by the Cochrane Eyes and Vision Group. One review author entered data into RevMan 5 (Review Manager 2011) and a second author verified all values.

Assessment of study characteristics-We extracted information on the following study characteristics:

- Methods: study design; method of randomization; unit of randomization (individuals/eyes); method of allocation concealment; number randomized; exclusions after randomization; number analyzed; masking (blinding); losses to follow-up; unit of analysis (individuals/eyes).

- Participants: country; age; gender; inclusion/exclusion criteria.

- Interventions: treatment (including dose and schedule); control; duration of treatment; length of follow-up (planned/actual); compliance. 
- Outcomes: relevant outcomes (definition, method of assessment, statistical methods used); eye examined or the outcome (worse/better/average); intervals at which each outcome was assessed; quality control for outcome assessment; adverse effects.

- Notes: study period; general health status of study population; types of subgroup analyses; control group event rate for dichotomous outcomes; power calculation (Yes/No, if yes whether appropriate); quality of life indicators; funding sources.

Assessment of risk of bias in included studies-Two authors independently assessed included trials for sources of systematic bias according to the guidelines in Chapter 8 of the Cochrane Handbook for Systematic Reviews of Interventions (Higgins 2011). We evaluated the trials for the following criteria: sequence generation and allocation concealment (selection bias), masking of care providers and recipients of care (performance bias), masking of outcome assessors (detection bias), incomplete outcome data (attrition bias), selective outcome reporting (reporting bias) and other sources of bias (intention-totreat analysis, equivalence of baseline characteristics and adherence to treatment). We reported the judgment for each criterion as low risk of bias, high risk of bias or unclear (information is insufficient to assess). We resolved disagreements through discussion. We contacted authors of the trials for additional information on issues that were unclear based on information available in the original report. In case of failure to communicate with the primary investigators, or if there was no response within six weeks, we assessed the methodological quality on the basis of the available information.

Measures of treatment effect-We extracted Cox proportional hazard ratios, unadjusted risk ratios and numbers and percentages for primary outcomes and difference in slope, adjusted and unadjusted odds ratios, unadjusted risk ratios, mean of last value and mean change from baseline for secondary outcomes.

For PHS II 2010, we calculated the Mantel-Haenszel risk ratio with 95\% confidence limits for incidence of cataract. For AREDS 2001, we calculated relative risks and 95\% confidence limits (from 99\% confidence intervals) for incidence of cataract extraction. For VECAT 2004, we calculated incidence of cataract extraction from values in the published study. For PPP 2001, we calculated incidence of cataract extraction from values obtained through personal communication. We used RevMan 5 to perform these calculations. Minor discrepancies at the second decimal place occurred with these data transformations.

Unit of analysis issues-The unit of analysis was the individual in all studies included in this review.

Dealing with missing data-We contacted primary authors of included trials for study methods and outcomes that were missing or not reported. We calculated relative risks (RR) and $95 \%$ confidence intervals (CI). We did not impute data.

Assessment of heterogeneity-We examined included trials for clinical heterogeneity by type of antioxidant, and by participant age, gender and country of origin. We did not pool 
results across antioxidant vitamin groups because of differences in their clinical properties. We examined statistical heterogeneity using the $\mathrm{Chi}^{2}$ test and $\mathrm{I}^{2}$ statistic.

Assessment of reporting biases-Although we planned to examine a funnel plot in conjunction with study characteristics or other factors that may contribute to asymmetry of the funnel plot to assess reporting biases, we chose not to include a funnel plot due to the limited number of included studies.

Data synthesis-We calculated summary relative risks for the incidence of cataract and cataract extraction, using the generic inverse variance method (fixed-effect model).

We did not pool results for the secondary outcomes because of differences in the definition of the outcomes as well as appreciable variability in the analysis and presentation of data. In such instances and in cases where only summary data or adjusted estimates were presented in the trial report, we used 'Other data tables' for presenting data.

Subgroup analysis and investigation of heterogeneity-We did not plan any subgroup analyses. However, we performed subgroup analysis by type of cataract (cortical, nuclear and posterior subcapsular) in instances where the data were available from the published report.

Sensitivity analysis-We planned to conduct sensitivity analyses by excluding trials that were at high risk of bias. As the majority of the trials that were pooled were large trials of high methodological quality, we did not conduct sensitivity analysis.

\section{RESULTS}

\section{Description of studies}

See: Characteristics of included studies; Characteristics of excluded studies; Characteristics of ongoing studies.

We describe the trials assessed for inclusion and exclusion in the 'Characteristics of included studies' and 'Characteristics of excluded studies' tables.

\section{Results of the search}

Selection of trials: We conducted electronic searches which yielded a total of 1861 reports of trials (Figure 1). We conducted manual searches of included and ongoing trials and also contacted study authors for information on other completed or ongoing trials. We screened titles and abstracts as per the inclusion criteria. We evaluated the full text of 31 reports of trials and a description of one trial from ClinicalTrials.gov. Eleven trials were eligible for inclusion; 21 were excluded. Among the 11 trials eligible for inclusion, one trial is complete, but data analysis is underway (WACS); the other trial is not yet open for participant recruitment (NCT01142960). Nine and six trials were included in the qualitative and quantitative synthesis respectively. 
Included studies: Nine trials (117,272 individuals), 'The Antioxidants in Prevention of Cataracts Study' (APC 2006), 'Age-Related Eye Disease Study' (AREDS 2001), 'The Alpha-tocopherol Beta-carotene Study' (ATBC 1998), 'Physician's Health Study I' (PHS I 2003), 'Physician's Health Study II' (PHS II 2010), 'The Primary Prevention Project' (PPP 2001), 'The Roche European American Cataract Trial' (REACT 2002), 'Vitamin E, Cataract and Age-related Maculopathy Trial' (VECAT 2004) and 'Women's Health Study' (WHS 2004/8) are included in this review.

The trials were conducted in Australia (VECAT 2004), Finland (ATBC 1998), India (APC 2006), Italy (PPP 2001), the United Kingdom (REACT 2002) and the United States of America (AREDS 2001; REACT 2002; PHS I 2003; PHS II 2010; WHS 2004/8) from 1982 to 2010. The duration of follow-up and treatment across these trials ranged from 2.1 to 12 years.

Types of participants: The participants in the included trials were 35 years or older. In three trials (ATBC 1998; PHS I 2003; PHS II 2010) participants were exclusively male and in one trial (WHS 2004/8) exclusively female. More women than men comprised the study population of the other five trials (APC 2006; AREDS 2001; PPP 2001; REACT 2002; VECAT 2004). In two trials (REACT 2002; VECAT 2004) participants were required to have some degree of age-related cataract at enrollment and in one trial (ATBC 1998) only those who smoked more than five cigarettes a day were included. Those with a history of intraocular surgery were excluded from participation in APC 2006, those with a history of cataract surgery were not included in VECAT 2004 and those who were likely to have cataract extraction within two years of enrollment were excluded from REACT 2002. Those already taking vitamin supplements were not considered for inclusion in four trials (APC 2006; ATBC 1998; REACT 2002; PHS I 2003; PHS II 2010).

Types of interventions: All included trials were controlled with placebo or alternate treatment; none of the trials had a 'no treatment' control.

Three trials (ATBC 1998; PHS I 2003; WHS 2004/8) evaluated beta-carotene alone, one trial (PHS II 2010) evaluated vitamin C alone, five trials (ATBC 1998; PHS II 2010; PPP 2001; VECAT 2004; WHS 2004/8) evaluated vitamin E alone, one trial (ATBC 1998) evaluated the combination of beta-carotene and vitamin E, one trial (PHS II 2010) evaluated the combination of vitamin $\mathrm{C}$ and vitamin $\mathrm{E}$ and three trials (APC 2006; AREDS 2001; REACT 2002) evaluated a combination of beta-carotene, vitamin $C$ and vitamin $E$.

In all trials, the dose of antioxidant vitamins was higher than the RDA. The dose of betacarotene in PHS I 2003 (50 mg on alternate days) placed those on treatment in the top few percentiles of the general population with respect to usual intake. The dose of beta-carotene was similar in WHS 2004/8, $50 \mathrm{mg}$ on alternate days. The dose of beta-carotene in ATBC 1998 (20 mg once daily) was higher than the RDA and the dose of vitamin E (50 mg once daily) was more than five times the RDA. The doses of vitamin C (500 mg once daily) and vitamin E (400 IU every other day) in PHS II 2010 exceeded usual dietary levels. The dose of vitamin E (300 mg/day) in PPP 2001 is significantly higher than the RDA. The dose of vitamin E in VECAT 2004 (500 IU daily) was higher than the RDA. The dose of vitamin E 
in WHS 2004/8 (600 IU every other day) was more than 13 times the RDA. The dose of the antioxidant vitamins (beta-carotene, vitamin $\mathrm{C}$, vitamin $\mathrm{E}$ ) were higher than the RDA in the three trials that evaluated the combination of these vitamins (APC 2006; AREDS 2001; REACT 2002). The dose in APC 2006 was beta-carotene, $15 \mathrm{mg}$; vitamin C, $500 \mathrm{mg}$; vitamin E, $400 \mathrm{IU}$ three times a week. The dose in AREDS 2001 was beta-carotene, $15 \mathrm{mg}$; vitamin C, $500 \mathrm{mg}$; vitamin E, 400 IU daily. The dose in REACT 2002 was beta-carotene, 6 $\mathrm{mg}$; vitamin C, $250 \mathrm{mg}$; alpha-tocopherol $200 \mathrm{mg}$ as a capsule three times daily.

\section{Types of outcome measures}

\section{Primary outcomes}

1. Incidence of cataract: Four trials (PHS I 2003; PHS II 2010; VECAT 2004; WHS 2004/8) evaluated incidence of cataract.

In PHS I 2003 and PHS II 2010, cataract was defined as an incident, age-related lens opacity responsible for a reduction in best-corrected visual acuity (BCVA) to 20/30 or worse, with no alternate ocular disease to explain the visual acuity loss. The assessment of incidence was based on self report confirmed by medical record review. Data from the 'worse eye' were analyzed. The results were presented as adjusted Cox proportional hazard ratios, with 95\% confidence intervals (CI).

In VECAT 2004, the incidence of the three major types of age-related cataract was assessed separately. Lens opacities were assessed clinically using the Wilmer Lens Grading system and objectively using the NIDEK lens camera. A cataract was considered present clinically (Wilmer Lens Grading System), if the incident cortical or nuclear opacity was grade 2 or more, or if the posterior subcapsular opacity was $1 \operatorname{millimeter}^{2}(\mathrm{~mm})$ or more. The change in grade had to be maintained for two consecutive years to be called an incident change. Data from the 'worse eye' were analyzed. The results were presented as unadjusted risk ratios (with 95\% CIs).

In WHS 2004/8, cataract was defined as a self report confirmed by medical record review to be initially diagnosed after randomization, age-related in origin, with BCVA of 20/30 or worse and no alternate ocular disease to explain the visual acuity loss. Data from the 'worse eye' were analyzed. The results were presented as Cox proportional hazard ratios (with 95\% CIs).

2. Incidence of cataract extraction: Eight trials (APC 2006; AREDS 2001; ATBC 1998; PHS I 2003; PHS II 2010; PPP 2001; VECAT 2004;WHS 2004/8) evaluated incidence of cataract extraction.

In APC 2006, cataract surgery was offered when BCVA decreased to 20/60 or worse or decreased visual acuity caused problems with everyday functioning. Data on BCVA assessment were unavailable to the authors of this review.

In AREDS 2001, events of cataract surgery were obtained from clinical reports. The results for cataract extraction were presented as both unadjusted relative risk and Cox proportional 
hazard ratios, with 99\% CIs adjusted for age, race, sex, baseline smoking status and agerelated macular degeneration.

In ATBC 1998, the incidence of cataract extraction was assessed separately for each of the interventions (beta-carotene alone, vitamin $\mathrm{E}$ alone and both). Cases were identified from the National Hospital Discharge Registry, which covered all hospitals performing cataract surgeries in Finland, using International Classification of Diseases codes. These codes do not differentiate the cataract types. The results were presented as incidence rate per 1000 person-years, with $95 \%$ CI. The results also were presented as Cox proportional hazard ratios (with 95\% CI) adjusted for baseline risk factors for cataract.

In PHS I 2003 and PHS II 2010, the assessment of incidence of cataract extraction was based on self report confirmed by medical record review. The results were presented as adjusted Cox proportional hazard ratios, with 95\% CI.

In PPP 2001, the incidence of cataract surgery was collected at final visit (personal communication).

In VECAT 2004, data on type of cataract that led to the surgery were obtained from the operating surgeon. The results were presented as counts and percentages for vitamin $\mathrm{E}$ and placebo (with the $\mathrm{P}$ value from the $\mathrm{Chi}^{2}$ test).

In WHS 2004/8, the assessment of incidence of cataract extraction was based on self report confirmed by medical record review. The results were presented as Cox proportional hazard ratios, with $95 \%$ CIs adjusted for aspirin and vitamin $\mathrm{E}$ treatment assignment, stratified by categories of age.

\section{Secondary outcomes}

1. Progression of cataract: Four trials (APC 2006; AREDS 2001; REACT 2002; VECAT 2004) evaluated progression of cataract.

In APC 2006, the progression of the three major types of age-related cataract was assessed separately. The primary outcome was change in nuclear opalescence from baseline as clinically evaluated by slit lamp using the Lens Opacities Classification System III (LOCS III) criteria. Secondary outcomes included change from baseline of nuclear color, cortical and posterior subcapsular opacities using the LOCS III criteria. The results were presented as difference in slope between the groups (with 95\% CI) from generalized estimating equations.

In AREDS 2001, the three major types of age-related cataract were assessed separately. Progression was defined in terms of events; a cortical event was defined as a change from baseline of $10 \%$ of the area of a standard central $5 \mathrm{~mm}$ circle; a nuclear event was defined as a change in opacity from baseline of $1.5 \mathrm{U}$ and a posterior subcapsular event was defined as a change from baseline of $5 \%$ of the area of a standard $5 \mathrm{~mm}$ circle. "Any lens event" included any of the above events or incident cataract surgery. "Severe lens event" included changes of $20 \%$ for cortical, $2.5 \mathrm{U}$ (units/steps) for nuclear, 20\% for posterior subcapsular cataracts. Slit lamp photographs were used to grade nuclear opacities and retroillumination 
photographs were used to estimate the area of involvement for cortical and posterior subcapsular opacities. The results were presented as odds ratios (with 99\% CI to account for multiple comparisons) from repeated measures logistic regression. For "any and severe lens event" both unadjusted and adjusted (for age, race, sex, baseline smoking status, age-related macular degeneration category) results were presented.

In REACT 2002, the primary outcome measure was increase in percent pixels opaque in the digital, anteriorly focused retroillumination image. Progression of cataract was defined as the difference between the last value and baseline value in percent pixels opaque. The three major types of age-related cataract were assessed separately using the LOCS III criteria: LOCS III C grade for cortical, LOCS III NO grade for nuclear and LOCS III P grade for posterior subcapsular cataract. The results were presented as mean of the last value, mean of change from baseline (with $\mathrm{P}$ values from analysis of variance) and as regression models from generalized estimating equations.

In VECAT 2004, the progression of the three major types of age-related cataract was assessed separately. Lens opacities were assessed clinically using the Wilmer Lens Grading system and objectively using masked grading of photos taken with the NIDEK lens camera. Progression was defined as (Wilmer Lens Grading System) an increase in cortical opacity by one grade or more, nuclear opacity by 0.5 of a grade or more and posterior subcapsular opacity by $1 \mathrm{~mm}^{2}$ or more. As stated earlier, the change in grade had to be maintained for two consecutive years to be considered as progression. The results were presented as unadjusted risk ratios (with $95 \% \mathrm{CI}$ ).

2. Loss of visual acuity: Three trials (APC 2006; AREDS 2001; REACT 2002) evaluated loss of visual acuity.

In APC 2006, visual acuity was evaluated using the National Eye Institute Early Treatment Diabetic Retinopathy Study (ETDRS) logMAR (logarithm of minimum angle of resolution) chart using standard methodology. The results were presented as change in BCVA from baseline (with standard deviation) at the end of the study.

In AREDS 2001, loss of visual acuity was defined as decrease in BCVA score from baseline of 15 or more letters which is equivalent to doubling of more of the initial visual angle. Visual acuity was measured every six months and was measured according to the ETDRS protocol. The results were presented as unadjusted and adjusted odds ratios (adjusted for age, race, sex, baseline smoking status), with $99 \%$ CIs from repeated measures logistic regression.

In REACT 2002, visual acuity was presented as mean of the last value and mean of change from baseline (with $P$ values from analysis of variance) on the logMAR scale. Visual acuity was assessed approximately every four months.

Excluded studies: We excluded 21 trials after full-text review. Among these, two trials, 'The Linxian Cataract Study' (LINXIAN 1993) and 'Lutein, but not alpha-tocopherol supplementation improves visual function in patients with age-related cataracts: a 2 year double blind, placebo controlled pilot study' (Olmedilla 2003) were excluded after detailed 
methodological review. The trial 'The role of antioxidants in the prevention of cancer and cardiovascular disease' (SUVIMAX 1998) was excluded after the principal investigator reported that 'eye' outcomes were not examined.

Risk of bias in included studies: Figure 2 and Figure 3 present a summary of the risk of bias for the included studies.

\section{Allocation}

Random sequence generation-We judged random sequence generation as unclear risk of bias for ATBC 1998 because it was not described in the published report. We judged random sequence generation to be at low risk of bias for the remaining eight studies included in this review. In APC 2006 randomization was performed in blocks of 40. In REACT 2002 Efron's biased coin method was used and in VECAT 2004 randomization was performed using permuted blocks. In AREDS 2001 the investigators used simple randomization stratified by clinical center and presence of age-related macular degeneration. Assignments were stored in two treatment assignment databases housed at the Co-ordinating Center. In PHS I 2003; PHS II 2010; PPP 2001; WHS 2004/8 randomization was performed using a computer-generated list of random numbers.

Method of allocation concealment-ATBC 1998 investigators did not describe the method of allocation concealment so we judged it as unclear risk of bias.

We judged the method of allocation concealment at low risk of bias for the remaining eight studies included in this review. In APC 2006, the placebo tablets were identical to active tablets in appearance and taste. In AREDS 2001, multiple unique bottle codes were randomly assigned to each treatment category; a bottle code corresponding to the assigned treatment was randomly selected for each participant. The AREDS study tablets were identical in external and internal appearance and taste. The co-ordinating center was the custodian of the treatment code. In PPP 2001, treatments were centrally assigned on telephone verification of the correctness of inclusion criteria with a separate computergenerated randomization table produced for each physician in random permuted blocks of 12. In REACT 2002, the individuals who prepared the randomization scheme were not involved in determining eligibility, administering the intervention or assessing the outcome. The task of generating the random assignment and the task of executing the assignment (consulting the assignment system for the participants intervention designation after determining eligibility) were performed by different individuals. The intervention assignment was not known to center administrators until the study was closed. It is unclear whether the study tablets were identical in external and internal appearance and taste. In VECAT 2004, the allocation list was stored at a remote site and the medications were dispensed in identical containers. All study information was obtained, collated and interpreted before the randomized assignment was broken. In PHS I 2003; PHS II 2010 and WHS 2004/8 the study pills in the treatment arms were identical except for the active agent in the beta-carotene group (personal communication). 
Blinding-We judged PPP 2001 at high risk of bias with regards to masking of care providers and participants. It is unclear whether the validation of clinical end points by an expert committee that was masked to the treatment assignment extended to the outcome of interest in this review (incidence of cataract extraction). Hence, overall we judged it to be at unclear risk of bias.

We judged masking at low risk of bias for the remainder of the eight studies included in this review. The care providers, participants and outcome assessors were masked in all these studies.

\section{Incomplete outcome data}

Losses to follow-up-In REACT 2002, 22\% ( $\mathrm{n}=66$ ) were lost after two years and 47\% $(\mathrm{n}=139)$ after three years. The authors report that the losses were equivalent between the intervention groups. We judged it as a high risk of bias.

In APC 2006, losses to follow-up were not reported in the published report. However, the losses to follow-up were equal across treatment groups (personal communication). In ATBC $1998,28.4 \%$ in the alpha-tocopherol group and $29.4 \%$ in the beta-carotene group were lost by the end of the trial. In VECAT 2004, 25.6\% $(n=152)$ in the treatment group and 23.8\% $(n=142)$ in the placebo group were lost by the end of the trial. We judged these as unclear risk of bias.

We judged the remaining five studies at low risk of bias. In AREDS 2001, 0.7\% $(n=33)$ of participants did not have at least one follow-up, however, $90 \%$ had at least five years of follow-up. Fourteen per cent withdrew from study medication after five years and $15 \%$ by the end of the trial (this includes those lost to follow-up and current smokers who withdrew from the study after the results of clinical trials of beta-carotene and lung cancer were announced).

In PHS I 2003, 99.2\% provided information on morbidity for 11 years into the study. In PHS II 2010, morbidity and mortality follow-up rates were $95.3 \%$ and $97.7 \%$ respectively. In PPP 2001 , losses to follow-up were $0.6 \%$ and $0.75 \%$ in the treatment and placebo arms respectively. In WHS 2004/8, morbidity and mortality follow-up rates at the termination of the beta-carotene arm (median 2.1 years) were $99 \%$ (personal communication) and for the vitamin E component $97.2 \%$ and $99.4 \%$ respectively.

Selective reporting-We did not identify any selective reporting across the nine trials that are included in this review. The results were reported for outcomes as described in the methods section in these trials. However, we did not have access to the study protocol for the nine trials.

\section{Other potential sources of bias}

Intention-to-treat analysis-We considered the analysis to be intention-to-treat as long as trial participants were analyzed in the groups to which they were randomized irrespective of which or how much treatment they actually received. 
Analysis was based on intention-to-treat for all nine trials included in this review.

In APC 2006; ATBC 1998; PHS I 2003; PHS II 2010; PPP 2001 and WHS 2004/8, data were analyzed according to the intention-to-treat principle, regardless of actual compliance.

In AREDS 2001, the authors report that the original treatment group assignments were retained for the analysis. Thirty-three $(0.7 \%)$ participants who did not have at least one follow-up were excluded from the analysis for "any lens event" and "incidence of cataract extraction" ('available case' analysis). The outcome 'visual acuity' was assessed in 1117 people without age-related macular degeneration at baseline. In REACT 2002, the authors report that the analysis was conducted on an intention-to-treat basis. The primary analysis was performed on completers at three years. Forty-seven per cent $(n=139)$ of those randomized were lost during this period. Additional analysis on "all randomized" was also performed. In VECAT 2004, the authors reported performing an "on protocol" (continuing study medication) and "off protocol" (cessation of study medication but continuing participation in the examinations) analysis in addition to intention-to-treat analysis. For incidence of any cataract, the first development of any of the three types of cataract was included in the numerator, but the cases in which any cataract was present at baseline were excluded. The denominator included all the cases of known outcome that were free of cataract at baseline. For progression, the numerator included cases of measured progression and the denominator included only those cases where assessment of progression was feasible.

Exclusions post randomization-In PHS II 2010, exclusions post randomization were high, 3096 or $21 \%$ of those randomized were excluded post randomization because of the presence of cataract at baseline. These were similar across treatment groups.

Exclusions post randomization were low to none in the remaining eight studies included in this review. In APC 2006, there were no exclusions after randomization (personal communication). In AREDS 2001, those with bilateral aphakia or pseudophakia ( $\mathrm{n}=128$, $2.7 \%$ of randomized) were participants for only the age-related macular degeneration part of the study and were excluded from the cataract trial. In ATBC 1998, those who had cataract extraction before enrolment ( $n=199,0.7 \%$ of randomized) were excluded from the analysis. In PHS I 2003, those with cataract at baseline $(n=1103,5 \%$ of those randomized $)$ were excluded from the analysis. The proportion of those excluded post randomization were equivalent across the two study groups. In PPP 2001, there were no exclusions post randomization. In REACT 2002, there were no exclusions post randomization; however only 'completers' at the end of the study were analyzed. In VECAT 2004, those not satisfying the age criteria ( $n=11,0.9 \%$ of randomized) were excluded. In WHS 2004/8 those who reported history of cataract at baseline $(n=3141,7.9 \%, n=2201,5.5 \%$ of randomized; for beta-carotene and vitamin $\mathrm{E}$ arms respectively) were excluded from the analysis. The proportions excluded were equivalent across the study groups.

Equivalence of baseline characteristics-In REACT 2002, participants from the United Kingdom were slightly older, had lower serum proteins, poorer liver function, lower vitamin levels, less brunescent lenses (opacity of the lens that is brownish in color) and more 
nuclear and cortical opacification. In the Australian study, VECAT 2004, the vitamin E arm had a greater number of cases of cortical and any cataract at baseline. We judged these studies to have an unclear risk of bias.

Important characteristics were equally distributed across the treatment groups in the remaining seven trials included in this review.

Adherence to treatment-Adherence to treatment was high for all nine trials included in this review.

In APC 2006, a field worker witnessed administration of active and identical appearing placebo tablets three times weekly. In AREDS 2001, adherence, defined as consumption of more than $75 \%$ of their study tablets, was estimated to be more than $75 \%$ for $70 \%$ of participants at five years. In ATBC 1998, 80\% of active participants (those coming for follow-up visits) were taking more than $95 \%$ of their capsules at each of the follow-up visits. In PHS I 2003, even after 11 years in the study, 78\% of the study pills were still reported as being taken. In PHS II 2010, compliance, defined as taking more than two-thirds of the study agents, was greater than $70 \%$ at the end of follow-up. In PPP 2001, $13.1 \%$ and $13.6 \%$ of those randomized to vitamin E were not taking the medication at year one and at the end of the study. In REACT 2002, compliance as assessed by plasma concentrations of antioxidant vitamins appears to be high. In VECAT 2004, 77\% of actively treated and 79\% of those in the placebo group were estimated to have consumed $80 \%$ or more of their capsules. In WHS 2004/8, 87\% of the beta-carotene arm reported taking at least two-thirds of study capsules, and $78.9 \%$ and $71.6 \%$ of vitamin E part of the trial were taking at least two-thirds of study capsules at five years and 10 years respectively.

The plasma concentrations of antioxidant vitamins were assessed in four studies (AREDS 2001; REACT 2002; VECAT 2004; WHS 2004/8). The result showed an increase in levels of the corresponding antioxidant vitamins assessed during follow-up.

\section{Effects of interventions}

\section{Primary outcomes}

1. Incidence of cataract-Four trials (PHS I 2003; PHS II 2010;VECAT 2004; WHS 2004/8) evaluated the incidence of cataract. We pooled the results for beta-carotene and vitamin E.

Beta-carotene versus placebo: Two trials (PHS I 2003; WHS 2004/8) compared betacarotene with placebo. In PHS I 2003, which evaluated 22,071 male physicians between 40 and 84 years in the United States, there was no difference between beta-carotene $(50 \mathrm{mg}$ on alternate days) and placebo in the risk of incidence of cataract over 12 years of follow-up. The Cox proportional hazard ratio adjusted for aspirin assignment was 1.0 (95\% confidence interval (CI) 0.91 to 1.09). In WHS 2004/8, which evaluated 39,876 female health professionals of age 45 years or older in the United States, there was no difference between beta-carotene (50 $\mathrm{mg}$ on alternate days) and placebo in the risk of incidence of cataract over 
a median period of 2.1 years. The Cox proportional hazard ratio adjusted for aspirin and vitamin $\mathrm{E}$ assignment was 0.95 (95\% CI 0.75 to 1.21 ).

In the pooled analysis of these two trials (PHS I 2003; WHS 2004/8) involving 57,703 participants, there was no evidence of effect of beta-carotene supplementation in reducing the risk of incidence of cataract. The summary relative risk (RR) was 0.99 (95\% CI 0.91 to 1.08). The test for heterogeneity was not statistically significant $\left(\mathrm{Chi}^{2}=0.15, \mathrm{P}=0.69 ; \mathrm{I}^{2}=\right.$ $0 \%$ ) (Analysis 1.1).

Vitamin C versus placebo: Only one trial (PHS II 2010) compared vitamin C with placebo. In this trial which evaluated 14,641 male physicians of age 50 years or older, there was no difference between vitamin C (500 $\mathrm{mg}$ daily) and placebo in the risk of incidence of cataract over a mean period of eight years of follow-up. The adjusted Cox proportional hazard ratio was 1.02 (95\% CI 0.91 to 1.14). There were no differences in risk by types of cataract (Analysis 2.1).

Vitamin E versus placebo: Three trials (PHS II 2010; VECAT 2004; WHS 2004/8) compared vitamin E with placebo. In PHS II 2010, there was no difference between vitamin E (400 IU daily) and placebo in the risk of incidence of cataract over a mean period of eight years of follow-up. The adjusted Cox proportional hazard ratio was 0.99 (95\% CI 0.88 to 1.11). In VECAT 2004, which evaluated 1204 volunteers between 55 and 80 years in Australia, there was no difference between vitamin E (500 IU daily) and placebo in the risk of incidence of any cataract over four years of follow-up. The risk ratio was 1.0 (95\% CI 0.8 to 1.4). In WHS 2004/8, there was no difference between vitamin E (600 IU on alternate days) and placebo in the risk of incidence of any cataract over an average of 9.7 years of follow-up. The Cox proportional hazard ratio adjusted for aspirin and beta-carotene assignments was 0.96 (95\% CI 0.88 to 1.04 ). There were no differences in risk by types of cataract.

In the pooled analysis of three trials (PHS II 2010; VECAT 2004; WHS 2004/8) involving 50,059 participants, there was no evidence of effect of vitamin $\mathrm{E}$ supplementation in reducing the risk of incidence of cataract. The summary RR was 0.97 (95\% CI 0.91 to 1.04 ). The test for heterogeneity was not statistically significant $\left(\mathrm{Chi}^{2}=0.22, \mathrm{P}=0.90 ; \mathrm{I}^{2}=0 \%\right)$. Similarly, in the subgroup analysis, there was no difference in effect by type of cataract. The RRs (95\% CIs) were 0.94 (0.84 to 1.04), 0.96 (0.90 to 1.03), 0.97 (0.86 to 1.09) for cortical, nuclear and posterior subcapsular cataract respectively (Analysis 3.1).

Vitamin C and vitamin E versus placebo: Only one trial (PHS II 2010) compared the combination of vitamin $\mathrm{C}$ and vitamin $\mathrm{E}$ with placebo. In this trial, there was no difference between the combination of vitamin C (500 mg daily) and vitamin E (400 mg IU on alternate days) with placebo in the risk of incidence of cataract over a mean period of eight years of follow-up. The Mantel-Haenszel risk ratio was 0.98 (95\% CI 0.84 to 1.15). There were no differences in risk by types of cataract (Analysis 5.1). 
2. Incidence of cataract extraction-Eight trials (APC 2006; AREDS 2001; ATBC 1998; PHS I 2003; PHS II 2010; PPP 2001; VECAT 2004; WHS 2004/8) reported incidence of cataract extraction. We pooled the results for beta-carotene and vitamin $\mathrm{E}$.

Beta-carotene versus placebo: Three trials (ATBC 1998; PHS I 2003; WHS 2004/8) compared beta-carotene with placebo. In ATBC 1998, which evaluated 29,133 male smokers between 50 and 69 years in Finland, there was no difference between beta-carotene (20 mg per day) and placebo in the risk of incidence of cataract extraction over a median period of 5.7 years of follow-up. The Cox proportional hazard ratio adjusted for risk factors for cataract was 0.97 (95\% CI 0.79 to 1.19). In PHS I 2003, there was no difference between the beta-carotene and placebo groups in the risk of incidence of cataract extraction over 12 years of follow-up. The Cox proportional hazard ratio adjusted for aspirin assignment was 1.00 (95\% CI 0.89 to 1.12). In WHS 2004/8, there was no difference between the betacarotene and placebo groups in the risk of incidence of cataract extraction over a median period of 2.1 years. The Cox proportional hazard ratio adjusted for aspirin and vitamin $\mathrm{E}$ assignment was 1.04 (95\% CI 0.78 to 1.39 ).

In the pooled analysis of three trials (ATBC 1998; PHS I 2003; WHS 2004/8) involving 86,836 participants there was no evidence of effect of beta-carotene supplementation in reducing the risk of cataract extraction. The summary RR was 1.0 (95\% CI 0.91 to 1.10 ). The test for heterogeneity was not statistically significant $\left(\mathrm{Chi}^{2}=0.15, \mathrm{P}=0.93 ; \mathrm{I}^{2}=0 \%\right)$ (Analysis 1.2).

Vitamin C versus placebo: Only one trial (PHS II 2010), compared vitamin C with placebo. In this trial, there was no difference between vitamin $\mathrm{C}$ and placebo in the risk of incidence of cataract over a mean period of eight years of follow-up. The adjusted Cox proportional hazard ratio was 0.97 (95\% CI 0.85 to 1.12). There were no differences in risk by types of cataract (Analysis 2.2).

Vitamin E versus placebo: Five trials (ATBC 1998; PHS II 2010; PPP 2001; VECAT 2004; WHS 2004/8) compared vitamin E with placebo. In ATBC 1998, there was no difference between vitamin $\mathrm{E}$ (50 mg once daily) and placebo in the incidence of cataract extraction over a median period of 5.7 years of follow-up. The Cox proportional hazard ratio adjusted for risk factors for cataract was 0.91 (95\% CI 0.74 to 1.11). In PHS II 2010, there was no difference between vitamin $\mathrm{E}$ and placebo in the risk of incidence of cataract extraction over a mean period of eight years of follow-up. The adjusted Cox proportional hazard ratio was 0.96 (95\% CI 0.83 to 1.10). There were no differences in risk by types of cataract. In PPP 2001, which evaluated 4495 volunteers of age 50 years or older in Italy, there was no difference between vitamin E ( $300 \mathrm{mg}$ daily) and placebo in the risk of incidence of cataract extraction over a mean period of 3.6 years of follow-up. The unadjusted risk ratio was 1.03 (95\% CI 0.73 to 1.46) (personal communication). In VECAT 2004, there was no difference between vitamin $\mathrm{E}$ and placebo in the risk of incidence of cataract extraction over four years of follow-up. The RR was 1.09 (95\% CI 0.69 to 1.72). In WHS 2004/8, there was no difference between vitamin $E$ and placebo in the risk of incidence of cataract extraction over an average of 9.7 years of follow-up. The Cox 
proportional hazard ratio adjusted for aspirin and beta-carotene assignments was 1.00 (95\% CI 0.91 to 1.11). There were no differences in risk by types of cataract.

Pooled analysis: In the pooled analysis of these five trials (ATBC 1998; PHS II 2010; PPP 2001; VECAT 2004;WHS 2004/8) involving 83,956 participants, there was no evidence of effect of vitamin E supplementation in reducing the risk of cataract extraction. The pooled $\mathrm{RR}$ is 0.98 (95\% CI 0.91 to 1.05). The test for heterogeneity was not statistically significant $\left(\mathrm{Chi}^{2}=1.04, \mathrm{P}=0.90 ; \mathrm{I}^{2}=0 \%\right)$. Similarly, in the subgroup analysis involving two trials (PHS II 2010; WHS 2004/8) there was no difference in effect by type of cataract. The RRs ( $95 \% \mathrm{CI}$ ) were 0.92 (0.81 to 1.05), 0.99 (0.91 to 1.07), 1.02 (0.89 to 1.16) for cortical, nuclear and posterior subcapsular cataract respectively (Analysis 3.2).

Beta-carotene plus vitamin E versus placebo: Only one trial (ATBC 1998) compared the combination of beta-carotene and vitamin $\mathrm{E}$ with placebo. In this trial, there was no difference between combined supplementation (beta-carotene with vitamin E) and placebo in the risk of incidence of cataract extraction over a median period of 5.7 years. The rate ratio for incidence of cataract extraction was 0.92 (95\% CI 0.70 to 1.21) (Analysis 4.1).

Beta-carotene plus vitamin C plus vitamin E versus placebo: Two trials (APC 2006; AREDS 2001) compared the combination of beta-carotene, vitamin $C$ and vitamin $E$ with placebo. Data from APC 2006 are unavailable. In AREDS 2001, which evaluated 4757 volunteers between 55 and 80 years in the United States, there was no difference between antioxidant and no antioxidant for the risk of cataract surgery over a mean period of 6.3 years. The Cox proportional hazard ratio adjusted for age, race, sex and smoking status was 0.97 (95\% CI 0.83 to 1.13 ) (Analysis 6.1).

\section{Secondary outcomes}

1. Progression of cataract-Four trials (APC 2006; AREDS 2001; REACT 2002; VECAT 2004) evaluated progression of cataract. We did not pool results because of differences in the definitions of the outcomes and differences in the analysis and presentation of data. Data from the primary studies are presented in 'Other data tables'.

No trials compared either beta-carotene or vitamin $\mathrm{C}$ with placebo.

Vitamin E versus placebo: Only one trial (VECAT 2004) compared vitamin E with placebo. In this trial, there was no difference between the vitamin $\mathrm{E}$ and placebo groups in the risk of progression of any cataract over four years of follow-up. The risk ratio was 1.0 (95\% CI 0.7 to 1.3). There was no difference in risk by types of cataract (Analysis 3.3).

Beta-carotene plus vitamin C plus vitamin $\mathbf{E}$ versus placebo: Three trials (APC 2006; AREDS 2001; REACT 2002) compared the combination of beta-carotene, vitamin C and vitamin E with placebo. In APC 2006, which evaluated 798 volunteers between 35 and 50 years in India, there was no difference between antioxidant (beta-carotene: $15 \mathrm{mg}$, vitamin C: $500 \mathrm{mg}$, vitamin E: $400 \mathrm{IU}$, three times a week) and placebo in the risk of progression of cataract over five years. The results were similar by type of cataract and by age groups. In AREDS 2001, there was no difference between antioxidant (beta-carotene: $15 \mathrm{mg}$, vitamin 
C: $500 \mathrm{mg}$, vitamin E: $400 \mathrm{IU}$ daily) and no antioxidant for the risk of any lens event (includes cataract surgery) over a mean period of 6.3 years. The odds ratio (OR) adjusted for age, race, gender, baseline smoking status and age-related macular degeneration category was 1.0 (95\% CI 0.90 to 1.11$)$. The results were similar for the risk of a severe lens event, OR 0.95 (95\% CI 0.82 to 1.10). There was also no difference in the risk by type of cataract. In REACT 2002, which evaluated 297 participants over 40 years in the United States and the United Kingdom, the generalized estimating equations with last values carried forward to account for dropouts, the increase in percent pixels opaque of placebo group compared to antioxidant group was 0.509 . However this difference, though in favor of antioxidants, was not statistically significant. The authors report finding a beneficial effect in the subgroups of those with no or early cataract irrespective of length of follow-up, and in those with moderate to more advanced cataracts in both the United States and the United Kingdom. However in this study $22 \%(\mathrm{n}=66)$ were lost after two years and $47 \%(\mathrm{n}=139)$ after three years of follow-up. In the ANOVA analysis of participants completing the study at three years, progression of cataract as defined by mean $(95 \% \mathrm{CI})$ increase in percent pixels opaque was $1.661(+/-0.984)$ in the antioxidant group as compared to $3.273(+/-1.406)$ in the placebo group, $\mathrm{P}=0.048$. The results were not statistically significant by type of cataract (assessed as increase in LOCS III C grade) (Analysis 6.2).

\section{Loss of visual acuity-Three studies (APC 2006; AREDS 2001;REACT 2002)} evaluated loss of visual acuity. All three studies examined a combination of beta-carotene, vitamin $\mathrm{C}$ and vitamin $\mathrm{E}$ with placebo.

Beta-carotene plus vitamin C plus vitamin E versus placebo: In APC 2006, there was no difference between antioxidant and placebo for change in visual acuity. The BCVA of the antioxidant group was a mean of 1.64 letters less (standard deviation (SD) 4.74) at year five compared to baseline while that of the placebo group was a mean of 1.66 letters less (SD 4.96). In AREDS 2001, there was no difference between antioxidant and placebo for the risk of loss of 15 or more letters in visual acuity score compared with baseline measurement over a mean period of 6.3 years. The OR from repeated measures logistic regression adjusted for age, race, sex and smoking status was 1.07 (95\% CI 0.74 to 1.54). In REACT 2002, there was no difference between antioxidant and placebo in $\log$ MAR visual acuity among completers over a period of three years. The mean change (95\% CI) in the antioxidant group was $-0.052(+/-0.027)$ as compared to $-0.073(+/-0.034)$ in the placebo group, $\mathrm{P}=0.189$ (Analysis 6.3).

Adverse effects: See additional Table 1'Adverse events: hypercarotenodermia'.

The proportion of participants developing hypercarotenodermia (yellowing of skin) while on beta-carotene was 8.6\% $(\mathrm{n}=203)$ in AREDS 2001, 8.8\% $(\mathrm{n}=1281)$ in ATBC 1998, 15.8\% $(\mathrm{n}=1745)$ in PHS I 2003 (data from PHS 1996), 7.4\% $(\mathrm{n}=6)$ in REACT 2002 and 10.7\% $(\mathrm{n}=2131)$ in WHS 2004/8 (data from WHS 1999).

In VECAT 2004, there was no statistically significant difference between the vitamin E and placebo groups on number and type of adverse events according to the body system 
involved. In WHS 2004/8, those on vitamin $\mathrm{E}$ had a statistically significant increase in risk of epistaxis (bleeding from the nose) (RR 1.06, 95\% CI 1.01 to 1.11).

\section{DISCUSSION}

\section{Summary of main results}

This review contains important findings regarding the failure of antioxidant vitamin supplementation to prevent and slow incidence and progression of age-related cataract.

The four trials that examined incidence of cataract did not find any evidence of effect for beta-carotene (PHS I 2003; WHS 2004/8) vitamin C (PHS II 2010), vitamin E (PHS II 2010; VECAT 2004; WHS 2004/8) or vitamin C and vitamin E in combination (PHS II 2010). Additionally, there was no evidence of effect of antioxidant supplementation by type of cataract with vitamin $\mathrm{C}$ and vitamin $\mathrm{E}$ supplementation either as single agents or in combination (PHS II 2010). Furthermore, our fixed-effect meta-analysis did not show any evidence of effect for beta-carotene or vitamin $\mathrm{E}$ on incidence of cataract.

The eight trials that examined incidence of cataract extraction did not find any evidence of effect for beta-carotene (ATBC 1998; PHS I 2003; WHS 2004/8), vitamin C (PHS II 2010), vitamin E (ATBC 1998; PHS II 2010; PPP 2001;VECAT 2004;WHS 2004/8) or betacarotene and vitamin $\mathrm{E}$ in combination (ATBC 1998), or all of the three in combination (AREDS 2001). Additionally, there was no evidence of effect by type of cataract with vitamin C (PHS II 2010) or vitamin E supplementation (PHS II 2010; VECAT 2004; WHS 2004/8). Our fixed-effect meta-analysis did not show any evidence of effect for either betacarotene or vitamin $\mathrm{E}$ on incidence of cataract extraction.

The four trials that examined progression of cataract, regardless of designation of type, did not find any evidence of effect for either vitamin E alone (VECAT 2004) or all three antioxidants in combination (APC 2006; AREDS 2001; REACT 2002). Progression of cataract was defined differently in these four trials. In REACT 2002, though the effect estimate for progression of cataract (as the primary outcome) favored antioxidant supplementation as reported by the authors, their finding should be interpreted with caution because of the high attrition rate in the trial. Moreover, the test of statistical significance for this outcome yielded a probability considered "borderline." None of the effect estimates for progression of cataract (as secondary outcomes) were statistically significant. Additionally, the results by type of cataract were not statistically significant. In VECAT 2004, the nonstatistically significant increase in progression of cataract (RR 2.5, 95\% CI 0.6 to 11.2) and the non-significant decrease in incidence of cataract (RR $0.5,95 \%$ CI 0.2 to 1.1 ) in the subgroup of posterior subcapsular cataract should be interpreted with caution because of the low event rates and very small sample size.

The three studies that examined loss of visual acuity did not find any evidence of a beneficial effect for all the three antioxidants in combination (APC 2006; AREDS 2001; REACT 2002). 


\section{Overall completeness and applicability of evidence}

A large number of trials have examined the role of antioxidant vitamins in relation to agerelated cataract. However, only 10 of these were randomized controlled trials with a followup of at least one year. Nine trials (117,272 individuals) with follow-up ranging from 2.1 to 12 years are included in this review. One trial (WACS) has been completed and data analysis is underway. The included trials were conducted in Australia (VECAT 2004), Finland (ATBC 1998), India (APC 2006), Italy (PPP 2001), the United Kingdom (REACT 2002) and the United States of America (AREDS 2001; REACT 2002; PHS I 2003; PHS II 2010; WHS 2004/8) from 1982 to 2010.

The population in these trials were 35 years or older and three (ATBC 1998; PHS I 2003; PHS II 2010) of these were conducted on men only. One trial (WHS 2004/8) was conducted exclusively on women. Two trials (REACT 2002; VECAT 2004) were secondary prevention trials in which participants were required to have some degree of age-related cataract at baseline. Three trials (ATBC 1998; PHS I 2003; WHS 2004/8) examined beta-carotene as a single agent, one trial examined vitamin C as a single agent (PHS II 2010) and five trials (ATBC 1998; PHS II 2010; PPP 2001; VECAT 2004; WHS 2004/8) examined vitamin E as a single agent. One trial (ATBC 1998) evaluated a combination of beta-carotene and vitamin E, another trial (PHS II 2010) evaluated a combination of vitamin C and vitamin $\mathrm{E}$ and three trials (APC 2006; AREDS 2001; REACT 2002) evaluated the combination of all these three antioxidant vitamins. Four trials (PHS I 2003; PHS II 2010; VECAT 2004; WHS 2004/8) evaluated the incidence of cataract. Eight trials (APC 2006; AREDS 2001; ATBC 1998; PHS I 2003; PHS II 2010; PPP 2001; VECAT 2004; WHS 2004/8) evaluated incidence of cataract extraction. Four trials (APC 2006; AREDS 2001; REACT 2002; VECAT 2004) evaluated progression of cataract and three studies (APC 2006; AREDS 2001; REACT 2002) evaluated loss of visual acuity. The doses of antioxidant supplementation were higher than the RDA in all trials.

This systematic review of world literature suggests that there is no evidence of effect of the antioxidant vitamins beta-carotene, vitamin $\mathrm{C}$ and vitamin $\mathrm{E}$ on the incidence of cataract, incidence of cataract extraction, progression of cataract or loss of visual acuity. Several characteristics of the populations of these studies are noteworthy. Firstly, these studies included only those aged 35 years or older. It is possible that supplementation should be started at an earlier age to demonstrate a beneficial effect. Secondly, the protective effect of antioxidant vitamins perhaps may take decades of intake to manifest. Thirdly, all the included studies except APC 2006 were done in the developed world on apparently healthy individuals. The nutritional status of these individuals could be quite different from those in the developing world. Lastly, there are many different types of antioxidants, some natural and some synthetic, and the conclusions drawn here should be limited to supplementation with beta-carotene, vitamin $\mathrm{C}$ and vitamin $\mathrm{E}$ only. It is possible that there are other antioxidants that are beneficial in relation to age-related cataract.

Though this systematic review did not find any protective effect for antioxidant vitamin supplementation, its results should not be extrapolated to imply that consumption of fruits and vegetables which are rich in antioxidant vitamins and other substances is not beneficial. The included studies used supplements in doses that were higher than the RDA for these 
antioxidant vitamins. It is possible that these doses are toxic. Fruits and vegetables contain safe amounts of antioxidants; only high levels of antioxidants that result from supplementation could be detrimental.

It has been suggested that beta-carotene may be a co-carcinogen (Paolini 2003). In this review, hypercarotenodermia (yellowing of skin) was observed in $7 \%$ or more of those taking beta-carotene among the participants of AREDS 2001, ATBC 1998, PHS I 2003, REACT 2002 and WHS 2004/8. There was a statistically significant 6\% increase in epistaxis among those taking vitamin E in participants of WHS 2004/8. Additionally, studies have shown that beta-carotene used as a single agent or in combination with vitamin $\mathrm{A}$ and vitamin E either had no effect or a statistically significant increase in mortality (Bjelakovic 2004; Caraballoso 2003; Vivekananthan 2003). In the light of no evidence of effect for betacarotene, vitamin $\mathrm{C}$ and vitamin $\mathrm{E}$ supplementation with respect to cataract and visual acuity and with evidence of adverse effects for beta-carotene and vitamin $\mathrm{E}$, recommendations for use should be made with a great degree of caution. It should be noted that as with beneficial effects, adverse effects for these antioxidant vitamins and adverse effects of other antioxidants may require decades of intake to manifest.

The use of antioxidant vitamin supplementation by the general population of western countries is probably high. According to data from the Women's Health Initiative more than half the women were taking antioxidants in some form (WHI 2003). In view of the lack of evidence of a protective effect of antioxidant vitamin supplementation and the increase in risk associated with its use, great efforts should be made to educate physicians and the public about their potential deleterious effects. The ease of availability of these antioxidant vitamins over the counter and aggressive marketing strategies make awareness of these issues a pressing public health necessity.

\section{Quality of the evidence}

We have been able to demonstrate, with high-quality evidence, the failure of antioxidant vitamin supplementation in preventing and slowing the progression of age-related cataract.

Only one trial (REACT 2002) was judged to be at 'high risk of bias' (for incomplete outcome data) with respect to the parameters of quality assessed in this review. However, this trial did not demonstrate any convincing evidence of effect and was not included in any meta-analysis.

Among the trials that were pooled, three (ATBC 1998; PPP 2001; VECAT 2004) were judged at 'unclear risk of bias' for select parameters of quality. It is possible for selection bias to have influenced the results of ATBC 1998. The care providers and participants were not masked in PPP 2001, and the losses to follow-up were high in ATBC 1998 and VECAT 2004. However, these trials did not demonstrate any evidence of effect and their contribution (weight) towards the pooled estimates were low. The weights were: ATBC $199812.9 \%$ and $21.4 \%$, PPP $20014.4 \%$ and VECAT $20042 \%$ to 5.5\%. The remainder of the trials that were pooled (PHS I 2003; PHS II 2010; WHS 2004/8) were of high methodological quality. 


\title{
Potential biases in the review process
}

We are unable to identify any significant biases in the review process.

We conducted a comprehensive search that included searching major databases, reference lists of published trials and contacting experts in this field for information on trials. To our knowledge, there are no other trials that have examined the antioxidant vitamins betacarotene, vitamin $\mathrm{C}$ and vitamin $\mathrm{E}$ in relation to age-related cataract that would have met the inclusion criteria. Data extraction was conducted in duplicate by two review authors; data entry and related analyses were entered by one author and verified by a second.

\section{Agreements and disagreements with other studies or reviews}

The results of the individual trials and the pooled analysis are similar. They failed to demonstrate any evidence of effect of antioxidant supplementation in preventing the formation and slowing the progression of age-related cataract. Additionally, this review failed to support observational studies that suggested beneficial effects with antioxidant vitamin supplementation.

\section{AUTHORS' CONCLUSIONS}

\section{Implications for practice}

There is no evidence from randomized controlled trials that antioxidant vitamin supplementation with beta-carotene, vitamin $\mathrm{C}$ and vitamin $\mathrm{E}$ prevents or slows the progression of age-related cataract. Costs and adverse effects should be weighed carefully with unproven benefits before recommending their use.

\section{Implications for research}

We do not recommend any further studies to examine the role of antioxidant vitamins betacarotene, vitamin $\mathrm{C}$ and vitamin $\mathrm{E}$ in preventing or slowing the progression of age-related cataract.

\section{Supplementary Material}

Refer to Web version on PubMed Central for supplementary material.

\section{ACKNOWLEDGEMENTS}

\begin{abstract}
We thank the Cochrane Eyes and Vision Group (CEVG) for preparing and executing the electronic searches for this review and the CEVG US satellite at Johns Hopkins Bloomberg School of Public Health for their assistance and guidance during the process of the review. We also thank Barbara Hawkins and Roberta Scherer for their comments on the review. We thank Anupa Shah, Managing Editor for CEVG for her assistance throughout the review process. We acknowledge Dr. Sankar Navaneethan (SN) for leading the development of the protocol for this review and Dr. Sarah Maier MD and Mr. Roland Remenyi for translating the Spanish and German articles.

Richard Wormald (Co-ordinating Editor for CEVG) acknowledges financial support for his CEVG research sessions from the Department of Health through the award made by the National Institute for Health Research to Moorfields Eye Hospital NHS Foundation Trust and UCL Institute of Ophthalmology for a Specialist Biomedical Research Centre for Ophthalmology. The views expressed in this publication are those of the authors and not necessarily those of the Department of Health.
\end{abstract}

\section{SOURCES OF SUPPORT}


Internal sources

- Memorial Hospital of Rhode Island/Brown University, USA.

- University of South Carolina, USA.

External sources

- Contract N01-EY-2-1003 and Grant 1 U01 EY020522-01, National Eye Institute, National Institutes of Health,USA, USA.

- Brown University, USA.

\section{REFERENCES}

* Indicates the major publication for the study

\section{References to studies included in this review}

APC 2006 \{published and unpublished data\} Gritz DC, Srinivasan M, Smith SD, Kim U, Lietman TM, Wilkins JH, et al. The Antioxidants in Prevention of Cataracts Study: effects of antioxidant supplements on cataract progression in South India. British Journal of Ophthalmology. 2006; 90(7): 847-851. [PubMed: 16556618]

AREDS 2001 \{published data only\} Age-Related Eye Disease Study Research Group. A randomized, placebo-controlled, clinical trial of high-dose supplementation with vitamins $\mathrm{C}$ and $\mathrm{E}$ and beta carotene for age-related cataract and vision loss: AREDS report no. 9. Archives of Ophthalmology. 2001; 119(10):1439-1452. [PubMed: 11594943]

ATBC 1998 \{published data only\} Teikari JM, Rautalahti M, Haukka J, Jarvinen P, Hartman AM, Virtamo J, et al. Incidence of cataract operations in Finnish male smokers unaffected by alpha tocopherol or beta carotene supplements. Journal of Epidemiology and Community Health. 1998; 52(7):468-472. [PubMed: 9799882]

PHS I 2003 \{published and unpublished data\} Christen WG, Manson JE, Glynn RJ, Gaziano JM, Sperduto RD, Buring JE, et al. A randomized trial of beta carotene and age-related cataract in US physicians. Archives of Ophthalmology. 2003; 121(3):372-378. [PubMed: 12617708]

PHS II 2010 \{published data only\} Christen WG, Glynn RJ, Sesso HD, Kurth T, MacFadyen J, Bubes $\mathrm{V}$, et al. Age-related cataract in a randomized trial of vitamins $\mathrm{E}$ and $\mathrm{C}$ in men. Archives of Ophthalmology. 2010; 128(11):1397-1405. [PubMed: 21060040]

PPP 2001 \{published and unpublished data\} Epidemiological feasibility of cardiovascular primary prevention in general practice: a trial of vitamin E and aspirin. Collaborative Group of the Primary Prevention Project. Journal of Cardiovascular Risk. 1995; 2(2):137-142. [PubMed: 7606650] Collaborative Group of the Primary Prevention Project. Low-dose aspirin and vitamin E in people at cardiovascular risk: a randomised trial in general practice. Lancet. 2001; 357(9250):89-95.

[PubMed: 11197445]

REACT 2002 \{published data only\} Chylack LT Jr, Brown NP, Bron A, Hurst M, Köpcke W, Thien U, et al. The Roche European American Cataract Trial (REACT): a randomized clinical trial to investigate the efficacy of an oral antioxidant micronutrient mixture to slow progression of agerelated cataract. Ophthalmic Epidemiology. 2002; 9(1):49-80. [PubMed: 11815895]

VECAT 2004 \{published data only\} McNeil JJ, Robman L, Tikellis G, Sinclair MI, McCarty CA, Taylor HR. Vitamin E supplementation and cataract: randomized controlled trial. Ophthalmology. 2004; 111(1):75-84. [PubMed: 14711717]

WHS 2004/8 \{published and unpublished data\} Christen WG, Glynn RJ, Chew EY, Buring JE. Vitamin E and age-related cataract in a randomized trial of women. Ophthalmology. 2008; 115(5): 822-829. [PubMed: 18067963] Christen WG, Glynn RJ, Sperduto RD, Chew EY, Buring JE. Agerelated cataract in a randomized trial of beta-carotene in women. Ophthalmic Epidemiology. 2004; 11(5):401-412. [PubMed: 15590586] 


\section{References to studies excluded from this review}

AREDS 2000 \{published data only\} Age-Related Eye Disease Study Research Group. The age-related eye disease study: a clinical trial of zinc and antioxidants - age-related eye disease study report no. 2. Journal of Nutrition. 2000; 130(5 Suppl):S1516-S1519.

Asensio-Sanchez 2002 \{published data only\} Asensio-Sanchez VM. AREDS and age-related macular degeneration [Estudio AREDS y degeneracion macular asociada a la edad]. Archivos de la Sociedad Espanola de Oftalmologia. 2002; 77(9):477-479. [PubMed: 12221538]

Augustin 2002 \{published data only\} Augustin AJ, Schmidt-Erfurth U. Critical comments on the ARED study [Kritische worte zur ARED-studie]. Ophthalmologe. 2002; 99(4):299-300. [PubMed: 12058508]

CTNS 2008 \{published data only\} Maraini G, Sperduto RD, Ferris F, Clemons TE, Rosmini F, et al. Clinical Trial of Nutritional Supplements and Age-Related Cataract Study Group. A randomized, double-masked, placebo controlled clinical trial of multivitamin supplementation for age-related lens opacities. Ophthalmology. 2008; 115(4):599-607. [PubMed: 18387406]

Diplock 1994 \{published data only\} Diplock AT. Antioxidants and disease prevention. Molecular Aspects of Medicine. 1994; 15(4):293-376. [PubMed: 7845187]

Floren 1994 \{published data only\} Floren LC, Zangwill AC, Schroeder DJ. Antioxidants may retard cataract formation. Annals of Pharmacotherapy. 1994; 28(9):1040-1042. [PubMed: 7803880]

Leske 1997 \{published data only\} Leske MC, Wu SY, Connell AM, Hyman L, Schachat AP. Lens opacities, demographic factors and nutritional supplements in the Barbados Eye Study. International Journal of Epidemiology. 1997; 26(6):1314-1322. [PubMed: 9447412]

Li 1993 \{published data only\} Li JY, Li B, Blot WJ, Taylor PR. Preliminary report on the results of nutrition prevention trials of cancer and other common diseases among residents in Linxian, China. Chinese Journal of Oncology. 1993; 15(3):165-181. [PubMed: 8261860]

LINXIAN 1993 \{published data only\} Sperduto RD, Hu TS, Milton RC, Zhao JL, Everett DF, Cheng $\mathrm{QF}$, et al. The Linxian cataract studies. Two nutrition intervention trials. Archives of Ophthalmology. 1993; 111(9):1246-1253. [PubMed: 8363468]

Mares-Perlman 2000 \{published data only\} Mares-Perlman JA, Lyle BJ, Klein R, Fisher AI, Brady WE, VandenLangenberg GM, et al. Vitamin supplement use and incident cataracts in a population-based study. Archives of Ophthalmology. 2000; 118(11):1556-1563. [PubMed: 11074813]

Olmedilla 2003 \{published data only\} Olmedilla B, Granado F, Blanco I, Vaquero M. Lutein, but not alpha-tocopherol, supplementation improves visual function in patients with age-related cataracts: a 2-y double-blind, placebo-controlled pilot study. Nutrition. 2003; 19(1):21-24. [PubMed: 12507634]

Phakan 1982 \{published data only\} Hockwin O, Weigelin E, Baur M. Supplement to the clinical study on the effectiveness of an anticataract preparation [Erganzungen zur klinischen studie uber die wirksamkeit eines antikatarakt-praparates]. Fortschritte der Ophthalmologie. 1985; 82(3):237239. [PubMed: 3897000] Hockwin O, Weigelin E, Baur M, Boutros G. Controlled clinical study on the efficacy of Phakan as an anticataract drug [Kontrollierte klinische studie uber die wirksamkeit von Phakan als anti-kataraktmedikament]. Fortschritte der Ophthalmologie. 1982; 79(3):179-183. [PubMed: 6764443] Pau H. Statistical analysis of conservative cataract therapy based on a controlled clinical study of the effectiveness of Phakan/Phakolen [Statistische analyse konservativer katarakt-therapie an hand der kontrollierten klinischen studie uber die wirksamkeit von Phakan/Phakolen]. Fortschritte der Ophthalmologie. 1984; 81(4):337-340. [PubMed: 6383986] Weigelin E. Results of clinical studies on drug modification of progressive lens opacities [Resultate klinischer studien uber die medikamentose beeinflussung fortschreitender linsentrubungen]. Klinische Monatsblatter fur Augenheilkunde. 1985; 186(6):462-467. [PubMed: 3900541]

Sackett 2002 \{published data only\} Sackett CS, Schenning S. The age-related eye disease study: the results of the clinical trial. Insight. 2002; 27(1):5-7. [PubMed: 11962062]

Schutt 2002 \{published data only\} Schutt F, Pauleikhoff D, Holz FG. Vitamins and trace elements in age-related macular degeneration. Current recommendations, based on the results of the AREDS study [Vitamine und spurenelemente bei altersabhangiger makuladegeneration. Aktuelle 
empfehlungen, basierend auf den resultaten der AREDS-studie]. Ophthalmologe. 2002; 99(4): 301-303. [PubMed: 12058509]

Seddon 1994 \{published data only\} Seddon JM, Christen WG, Manson JE, LaMotte FS, Glynn RJ, Buring JE, et al. The use of vitamin supplements and the risk of cataract among US male physicians. American Journal of Public Health. 1994; 84(5):788-792. [PubMed: 8179050]

Seth 1999 \{published data only\} Seth RK, Kharb S. Protective function of alpha-tocopherol against the process of cataractogenesis in humans. Annals of Nutrition and Metabolism. 1999; 43(5):286289. [PubMed: 10749028]

Sharma 1989 \{published data only\} Sharma YR, Vajpayee RB, Bhatnagar R, Mohan M, Azad RV, Kumar M, et al. Systemic aspirin and systemic vitamin $\mathrm{E}$ in senile cataracts: cataract V. Indian Journal of Ophthalmology. 1989; 37(3):134-141. [PubMed: 2632449]

Shiriaeva 1987 \{published data only\} Shiriaeva LI, Dudnikova LK, Vakhrusheva LL, Gei AK, Skripkina VM. Use of vitamin E in children with diabetic ophthalmopathies [Primenenie vitamina E pri diabeticheskikh oftal'mopatiiakh u detei]. Pediatriia. 1987; 6:103. [PubMed: 3309867]

SUVIMAX 1998 \{published data only\} Vazquez-Martinez C, Galan P, Preziosi P, Ribas L, Serra LL, Hercberg S. The SUVIMAX (France) study: the role of antioxidants in the prevention of cancer and cardiovascular disorders [Estudio SUVIMAX (Francia): el papel de los antioxidantes en la prevencion del cancer y la enfermedad cardiovascular]. Revista Espanola de Salud Publica. 1998; 72(3):173-183. [PubMed: 9810825]

Teikari 1997 \{published data only\} Teikari JM, Virtamo J, Rautalahti M, Palmgren J, Liesto K, Heinonen OP. Long-term supplementation with alpha-tocopherol and beta-carotene and agerelated cataract. Acta Ophthalmologica Scandinavica. 1997; 75(6):634-640. [PubMed: 9527321]

Zrenner 2001 \{published data only\} Zrenner E, Ruther K. Administration of vitamin A derivatives in hereditary retinal degeneration. Status of recommendations [Gabe von Vitamin-A-derivaten bei erblichen netzhautdegenerationen. Stand der empfehlungen]. Ophthalmologe. 2001; 98(6):526528. [PubMed: 11450474]

\section{References to ongoing studies}

NCT01142960 \{published data only\} NCT01142960. Effects of vitamin C and lycium barbarum supplements on the progression of senile cataract in Hong Kong Chinese population. clinicaltrials.gov/ct2/show/NCT01142960.

WACS \{published data only\} Manson JE, Gaziano JM, Spelsberg A, Ridker PM, Cook NR, Buring JE, et al. A secondary prevention trial of antioxidant vitamins and cardiovascular disease in women. Rationale, design, and methods. The WACS Research Group. Annals of Epidemiology. 1995; 5(4):261-269. [PubMed: 8520707]

\section{Additional references}

Abraham 2006 Abraham AG, Condon NG, West Gower E. The new epidemiology of cataract. Ophthalmology Clinics of North America. 2006; 19(4):415-425. [PubMed: 17067897]

Bjelakovic 2004 Bjelakovic G, Nikolova D, Simonetti RG. Antioxidant supplements for prevention of gastrointestinal cancers: a systematic review and meta-analysis. Lancet. 2004; 364(9441):1219_ 1228. [PubMed: 15464182]

Blondin 1986 Blondin J, Baragi V, Schwartz E, Sadowski JA, Taylor A. Delay of UV-induced eye lens protein damage in guinea pigs by dietary ascorbate. Journal of Free Radical Biology and Medicine. 1986; 2(4):275-281.

Brown 1999 Brown L, Rimm EB, Seddon JM, Giovannucci EL, Chasan-Taber L, Spiegelman D, et al. A prospective study of carotenoid intake and risk of cataract extraction in US men. American Journal of Clinical Nutrition. 1999; 70(4):517-524. [PubMed: 10500021]

Burton 1984 Burton GW, Ingold KU. Beta-carotene: An unusual type of lipid antioxidant. Science. 1984; 224(4649):569-573. [PubMed: 6710156]

Caraballoso 2003 Caraballoso M, Sacristan M, Serra C. Drugs for preventing lung cancer in health people. Cochrane Database of Systematic Reviews. 2003; (Issue 2) 
Chasan-Taber 1999 Chasan-Taber L, Willett WC, Seddon JM, Stampfer MJ, Rosner B, Colditz GA, et al. A prospective study of vitamin supplement intake and cataract extraction among U.S. women. Epidemiology. 1999; 10(6):679-684. [PubMed: 10535780]

Congdon 2004 Congdon N, Vingerling JR, Klein BE, West S, Friedman DS, Kempen J, et al. Prevalence of cataract and pseudophakia/aphakia among adults in the United States. Archives of Ophthalmology. 2004; 122(4):487-494. [PubMed: 15078665]

Cumming 2000 Cumming RG, Mitchell P, Smith W. Diet and cataract: the Blue Mountains Eye Study. Ophthalmology. 2000; 107(3):450-456. [PubMed: 10711880]

Ellwein 2002 Ellwein LB, Urato CJ. Use of eye care and associated charges among the Medicare population 1991-1998. Archives of Ophthalmology. 2002; 120(6):804-811. [PubMed: 12049587]

GDVI 2004 Resnikoff S, Pascolini D, Etya'ale D, Kocur I, Pararajasegaram R, Pokharel GP, et al. Global data on visual impairment in the year 2002. Bulletin of the World Health Organization. 2004; 82(11):844-851. [PubMed: 15640920]

Glanville 2006 Glanville JM, Lefebvre C, Miles JN, Camosso-Stefinovic J. How to identify randomized controlled trials in MEDLINE: ten years on. Journal of the Medical Library Association. 2006; 94(2):130-136. [PubMed: 16636704]

Hankinson 1992 Hankinson SE, Stampfer MJ, Seddon JM, Colditz GA, Rosner B, Speizer FE, et al. Nutrient intake and cataract extraction in women: a prospective study. BMJ. 1992; 305(6849): 335-339. [PubMed: 1392884]

Higgins 2011 Higgins JPT, Altman DG, Sterne JAC, Higgins JPT, Green S. Chapter 8: Assessing risk of bias in included studies. Cochrane Handbook for Systematic Reviews of Interventions Version 5.1.0. updated March 2011The Cochrane Collaboration, 2011. Available from www.cochranehandbook.org.

IACS 1991 Anonymous. Risk factors for age-related cortical, nuclear, and posterior subcapsular cataracts. The Italian-American Cataract Study Group. American Journal of Epidemiology. 1991; 133(6):541-553. [PubMed: 1672483]

Jacques 1988 Jacques PF, Chylack LT Jr, McGandy RB, Hartz SC. Antioxidant status in persons with and without senile cataract. Archives of Ophthalmology. 1988; 106(3):337-340. [PubMed: 3345151]

Jacques 1991 Jacques PF, Chylack LT Jr. Epidemiologic evidence of a role for the antioxidant vitamins and carotenoids in cataract prevention. American Journal of Clinical Nutrition. 1991; 53(1 Suppl):S351-S355.

Jacques 1997 Jacques PF, Taylor A, Hankinson SE, Willett WC, Mahnken B, Lee Y, et al. Long-term vitamin $C$ supplement use and prevalence of early age-related lens opacities. American Journal of Clinical Nutrition. 1997; 66(4):911-916. [PubMed: 9322567]

Jacques 2001 Jacques PF, Chylack LT Jr, Hankinson SE, Khu PM, Rogers G, Friend J, et al. Longterm nutrient intake and early age-related nuclear lens opacities. Archives of Ophthalmology. 2001; 119(7):1009-1019. [PubMed: 11448323]

Karslioglu 2004 Karslioglu I, Ertekin MV, Kocer I, Taysi S, Sezen O, Gepdiremen A, et al. Protective role of intramuscularly administered vitamin $\mathrm{E}$ on the levels of lipid peroxidation and the activities of antioxidant enzymes in the lens of rats made cataractous with gamma-irradiation. European Journal of Ophthalmology. 2004; 14(6):478-485. [PubMed: 15638096]

Knekt 1992 Knekt P, Heliovaara M, Rissanen A, Aromaa A, Aaran RK. Serum antioxidant vitamins and risk of cataract. BMJ. 1992; 305(6866):1392-1394. [PubMed: 1486302]

Kuzniarz 2001 Kuzniarz M, Mitchell P, Cumming RG, Flood VM. Use of vitamin supplements and cataract: the Blue Mountains Eye Study. American Journal of Ophthalmology. 2001; 132(1):19_ 26. [PubMed: 11438049]

Leske 1991 Leske MC, Chylack LT Jr, Wu SY. The Lens Opacities Case-Control Study. Risk factors for cataract. Archives of Ophthalmology. 1991; 109(2):244-251. [PubMed: 1993036]

Leske 1995 Leske MC, Wu SY, Hyman L, Sperduto R, Underwood B, Chylack LT, et al. Biochemical factors in the lens opacities. Case-control study. The Lens Opacities Case-Control Study Group. Archives of Ophthalmology. 1995; 113(9):1113-1119. [PubMed: 7661743] 
Leske 1998 Leske MC, Chylack LT Jr, He Q, Wu SY, Schoenfeld E, Friend J, et al. Antioxidant vitamins and nuclear opacities: the longitudinal study of cataract. Ophthalmology. 1998; 105(5): 831-836. [PubMed: 9593382]

Leyland 2006 Leyland M, Pringle E. Multifocal versus monofocal intraocular lenses after cataract extraction. Cochrane Database of Systematic Reviews. 2006; (Issue 4) DOI: 10.1002/14651858.CD003169.pub2.

Libondi 1985 Libondi T, Menzione M, Auricchio G. In vitro effect of alpha-tocopherol on lysophosphatidylcholine-induced lens damage. Experimental Eye Research. 1985; 40(5):661-666. [PubMed: 4007079]

Lyle 1999 Lyle BJ, Mares-Perlman JA, Klein BE, Klein R, Greger JL. Antioxidant intake and risk of incident age-related nuclear cataracts in the Beaver Dam Eye Study. American Journal of Epidemiology. 1999; 149(9):801-809. [PubMed: 10221316]

Mares-Perlman 1994 Mares-Perlman JA, Klein BE, Klein R, Ritter LL. Relation between lens opacities and vitamin and mineral supplement use. Ophthalmology. 1994; 101(2):315-325. [PubMed: 8115152]

Mares-Perlman 1995 Mares-Perlman JA, Brady WE, Klein BE, Klein R, Haus GJ, Palta M, et al. Diet and nuclear lens opacities. American Journal of Epidemiology. 1995; 141(4):322-344. [PubMed: 7840110]

McCarty 1999 McCarty CA, Mukesh BN, Fu CL, Taylor HR. The epidemiology of cataract in Australia. American Journal of Ophthalmology. 1999; 128(4):446-465. [PubMed: 10577586]

Milton 2006 Milton RC, Sperduto RD, Clemons TE, Ferris FL 3rd. Age-Related Eye Disease Study Research Group. Centrum use and progression of age-related cataract in the Age-Related Eye Disease Study: a propensity score approach. AREDS report No. 21. Ophthalmology. 2006; 113(8): 1264-1270. [PubMed: 16877067]

Mohan 1989 Mohan M, Sperduto RD, Angra SK, Milton RC, Mathur RL, Underwood BA, et al. India-US case-control study of age-related cataracts. India-US Case-Control Study Group. Archives of Ophthalmology. 1989; 107(5):670-676. [PubMed: 2818712]

Nadalin 1999 Nadalin G, Robman LD, McCarty CA, Garrett SK, McNeil JJ, Taylor HR. The role of past intake of vitamin E in early cataract changes. Ophthalmic Epidemiology. 1999; 6(2):105-112. [PubMed: 10420210]

Ohta 1996 Ohta Y, Okada H, Majima Y, Ishiguro I. Anticataract action of vitamin E: its estimation using an in vitro steroid cataract model. Ophthalmic Research. 1996; 28(Suppl 2):16-25. [PubMed: 8883085]

Paolini 2003 Paolini M, Abdel-Rahman SZ, Sapone A. Beta-carotene: A cancer chemoprotective agent or a co-carcinogen? Mutation Research. 2003; 543(3):195-200. [PubMed: 12787812]

PBA 2008 Prevent Blindness America. Vision Problems in the U.S. Prevalence of Adult Vision Impairment and Age-Related Eye Disease in America. www.preventblindness.net/site/DocServer/ VPUS.2008.update.pdf.

PHS 1996 Hennekens CH, Buring JE, Manson JE, Stampfer M, Rosner B, Cook NR, et al. Lack of effect of long-term supplementation with beta carotene on the incidence of malignant neoplasms and cardiovascular disease. New England Journal of Medicine. 1996; 334(18):1145-1149. [PubMed: 8602179]

Review Manager 2011 The Cochrane Collaboration, The Nordic Cochrane Centre. Review Manager (RevMan). 5.1. 2011CopenhagenThe Cochrane Collaboration, The Nordic Cochrane Centre

Riaz 2006 Riaz Y, Mehta Jod S, Wormald R, Evans JR, Foster A, Ravilla T, et al. Surgical interventions for age-related cataract. Cochrane Database of Systematic Reviews. 2006; (Issue 4)

Robertson 1989 Robertson JM, Donner AP, Trevithick JR. Vitamin E intake and risk of cataracts in humans. Annals of the New York Academy of Sciences. 1989; 570:372-382. [PubMed: 2629606]

Robertson 1991 Robertson JM, Donner AP, Trevithick JR. A possible role for vitamins C and E in cataract prevention. American Journal of Clinical Nutrition. 1991; 53(Suppl 1):S346-S351.

Rouhiainen 1996 Rouhiainen P, Rouhiainen H, Salonen JT. Association between low plasma vitamin E concentration and progression of early cortical lens opacities. American Journal of Epidemiology. 1996; 144(5):496-500. [PubMed: 8781465] 
Tavani 1996 Tavani A, Negri E, La Vecchia C. Food and nutrient intake and risk of cataract. Annals of Epidemiology. 1996; 6(1):41-46. [PubMed: 8680624]

Taylor 2002 Taylor A, Jacques PF, Chylack LT Jr, Hankinson SE, Khu PM, Rogers G, et al. Longterm intake of vitamins and carotenoids and odds of early age-related cortical and posterior subcapsular lens opacities. American Journal of Clinical Nutrition. 2002; 75(3):540-549. [PubMed: 11864861]

Varma 1982 Varma SD, Beachy NA, Richards RD. Photoperoxidation of lens lipids: prevention by vitamin E. Photochemistry and Photobiology. 1982; 36(6):623-626. [PubMed: 7156212]

Vitale 1993 Vitale S, West S, Hallfrisch J, Alston C, Wang F, Moorman C, et al. Plasma antioxidants and risk of cortical and nuclear cataract. Epidemiology. 1993; 4(3):195-203. [PubMed: 8512984]

Vivekananthan 2003 Vivekananthan DP, Penn MS, Sapp SK, Hsu A, Topol EJ. Use of antioxidant vitamins for the prevention of cardiovascular disease: meta-analysis of randomized trials. Lancet. 2003; 361(9374):2017-2023. [PubMed: 12814711]

West 1995 West SK, Valmadrid CT. Epidemiology of risk factors for age-related cataract. Survey of Ophthalmology. 1995; 39(4):323-334. [PubMed: 7725232]

Wevill 2008 Wevill M. Yanoff M, Duker JS. Epidemiology, pathophysiology, causes, morphology, and visual effects of cataract. Ophthalmology (3rd Edition). 2008Mosby

WHI 2003 Shikany JM, Patterson RE, Agurs-Collins T, Anderson G. Antioxidant supplement use in the Women's Health Initiative. Preventive Medicine. 2003; 36(3):379-387. [PubMed: 12634029]

WHS 1999 Lee IM, Cook NR, Manson JE, Buring JE, Hennekens CH. Beta-carotene supplementation and incidence of cancer and cardiovascular disease: the Women's Health Study. Journal of the National Cancer Institute. 1999; 91(24):2102-2106. [PubMed: 10601381]

Yoshida 2007 Yoshida M, Takashima Y, Inoue M, Iwasaki M, Otani T, Sasaki S, et al. Prospective study showing that dietary vitamin $\mathrm{C}$ reduced the risk of age-related cataracts in a middle-aged Japanese population. European Journal of Nutrition. 2007; 46(2):118-124. [PubMed: 17265171]

\section{APPENDICES}

\section{Appendix 1}

\section{CENTRAL search strategy}

\#1 MeSH descriptor beta Carotene

\#2 beta carotene*

\#3 MeSH descriptor Ascorbic Acid

\#4 ascorbic acid*

\#5 vitamin $\mathrm{C}$

\#6 MeSH descriptor Vitamin E

\#7 MeSH descriptor alpha-Tocopherol

\#8 alphatocopherol*

\#9 alpha tocopherol*

\#10 vitamin $\mathrm{E}$

\#11 (\#1 OR \#2 OR \#3 OR \#4 OR \#5 OR \#6 OR (\#7 AND \#8) OR \#9 OR \#10)

\#12 MeSH descriptor Cataract

\#13 cataract* 
\#14 (\#12 OR \#13)

\#15 (\#11 AND \#14)

\section{Appendix 2}

\section{MEDLINE (OvidSP) search strategy}

1. randomized controlled trial.pt.

2. (randomized or randomised).ab,ti.

3. placebo.ab,ti.

4. dt.fs

5. randomly.ab,ti.

6. trial.ab,ti.

7. groups.ab,ti.

8. or/1-7

9. $\exp$ animals/

10. exp humans/

11. 9 not (9 and 10)

12. 8 not 11

13. exp beta carotene/

14. caroten $\$ . t w$.

15. exp ascorbic acid/

16. ascorbic acid\$.tw.

17. vitamin C.tw.

18. exp Vitamin E/

19. alpha?tocopherol\$.tw.

20. alpha tocopherol\$.tw.

21. vitamin E.tw.

22. or $/ 13-21$

23. exp cataract/

24. cataract\$.tw.

25. or $/ 23-24$

26. 22 and 25

27. 12 and 26 
The search filter for trials at the beginning of the MEDLINE strategy is from the published paper by Glanville et al (Glanville 2006).

\section{Appendix 3}

\section{EMBASE (OvidSP) search strategy}

1. exp randomized controlled trial/

2. exp randomization/

3. exp double blind procedure/

4. exp single blind procedure/

5. random\$.tw.

6. or $/ 1-5$

7. (animal or animal experiment).sh.

8. human.sh.

9. 7 and 8

10. 7 not 9

11. 6 not 10

12. exp clinical trial/

13. (clin $\$$ adj3 trial\$).tw.

14. ( ( singl\$ or doubl\$ or trebl\$ or tripl\$) adj3 (blind $\$$ or mask $\$)$ ).tw.

15. exp placebo/

16. placebo\$.tw.

17. random $\$ . t w$.

18. exp experimental design/

19. exp crossover procedure/

20. exp control group/

21. exp latin square design/

22. or $/ 12-21$

23. 22 not 10

24. 23 not 11

25. exp comparative study/

26. exp evaluation/

27. exp prospective study/ 
28. (control $\$$ or prospectiv $\$$ or volunteer $\$$ ).tw.

29. or $/ 25-28$

30. 29 not 10

31. 30 not (11 or 23$)$

32. 11 or 24 or 31

\section{Appendix 4}

\section{LILACS search strategy}

beta carotene or vitamin $\mathrm{C}$ or vitamin $\mathrm{E}$ and cataract\$

\section{Appendix 5 \\ OpenGrey search strategy \\ (beta carotene OR vitamin C OR vitamin E) AND cataract}

\section{Appendix 6}

metaRegister of Controlled Trials search strategy

(vitamin c or vitamin e or beta carotene) and cataracts

\section{Appendix 7}

ClinicalTrials.gov search strategy

(Vitamin C or Vitamin E or beta carotene) AND Cataract

\section{Appendix 8}

ICTRP search strategy

cataract $=$ condition AND vitamin or beta carotene $=$ intervention 


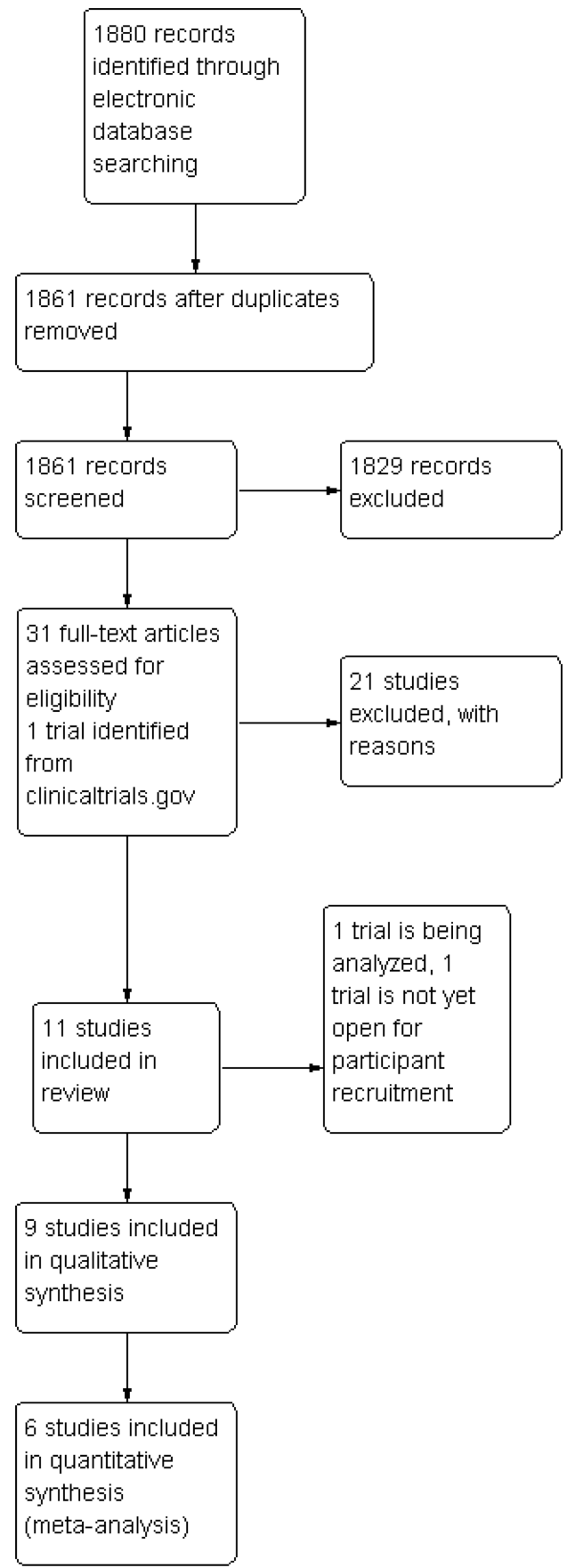

Figure 1.

Results from searching for studies for inclusion in the review. 


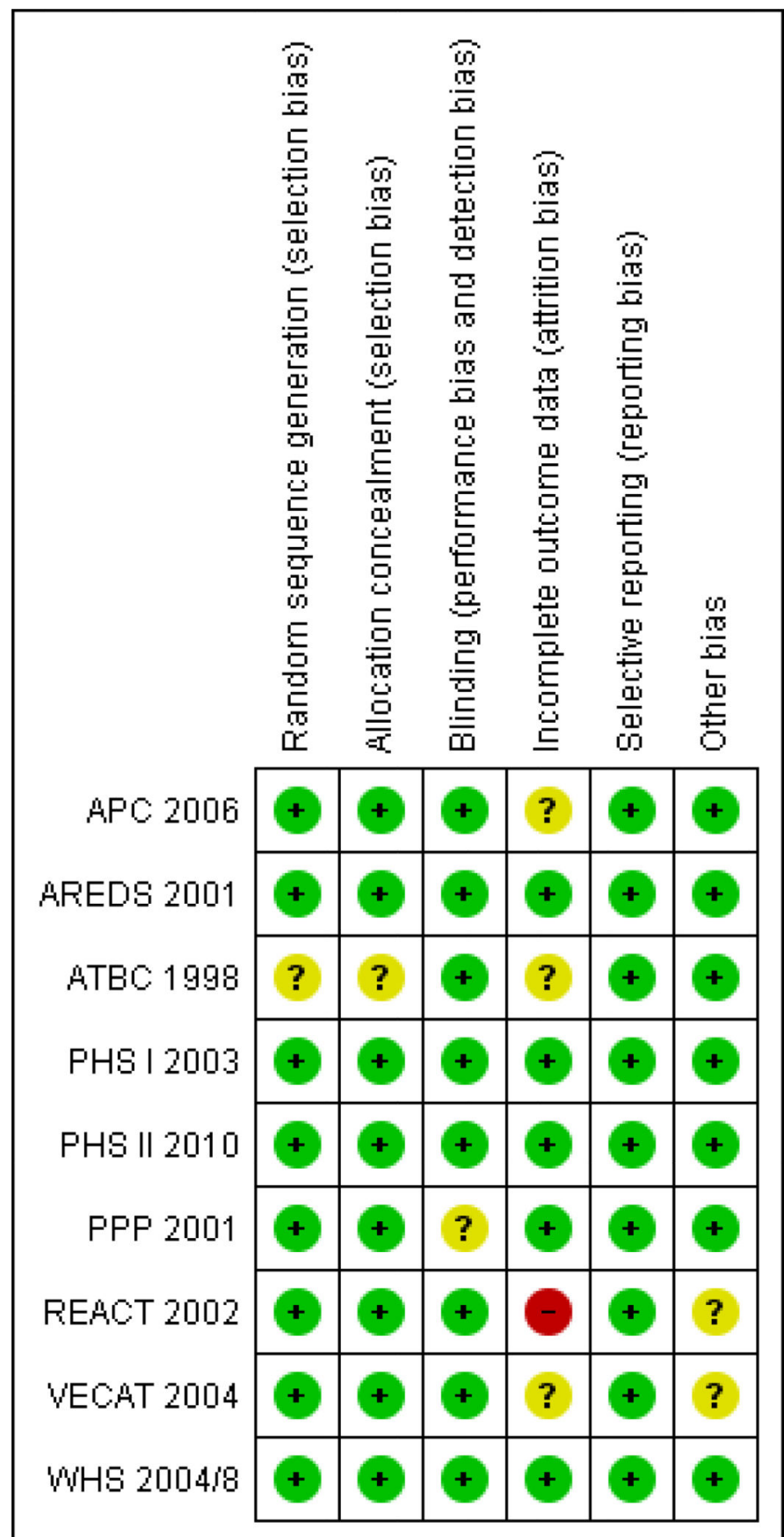

Figure 2.

'Risk of bias' summary: review authors' judgments about each risk of bias item for each included study. 


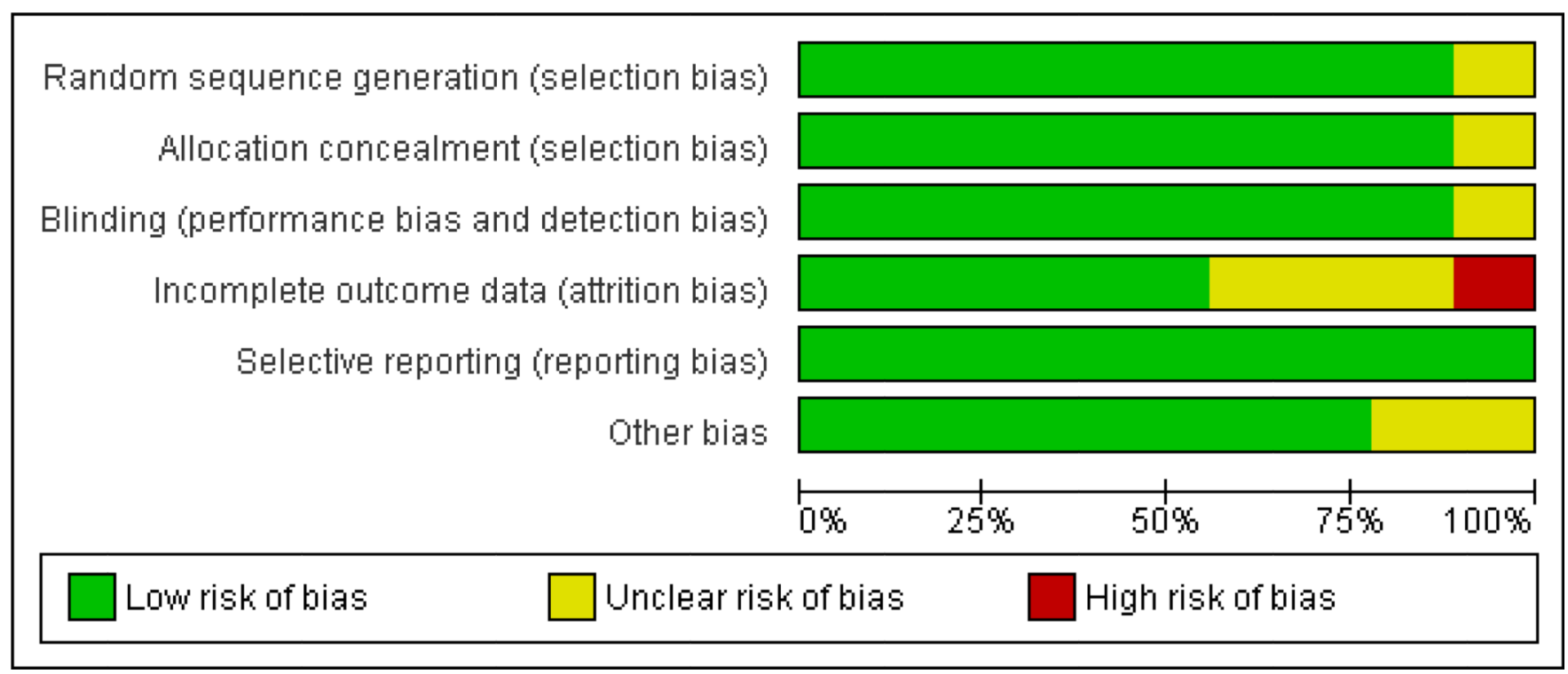

Figure 3.

'Risk of bias' graph: review authors' judgments about each risk of bias item presented as percentages across all included studies. 


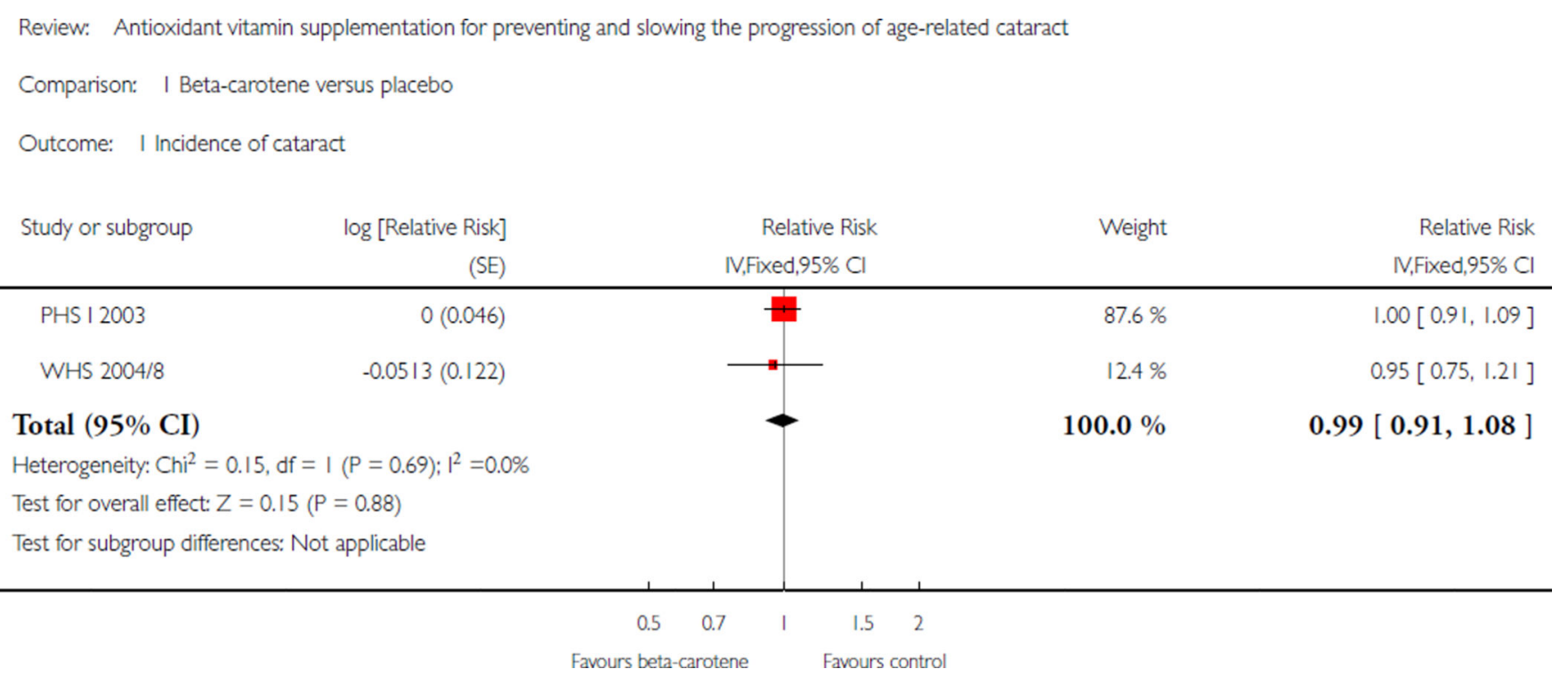

Analysis 1.1.

Comparison 1 Beta-carotene versus placebo, Outcome 1 Incidence of cataract. 


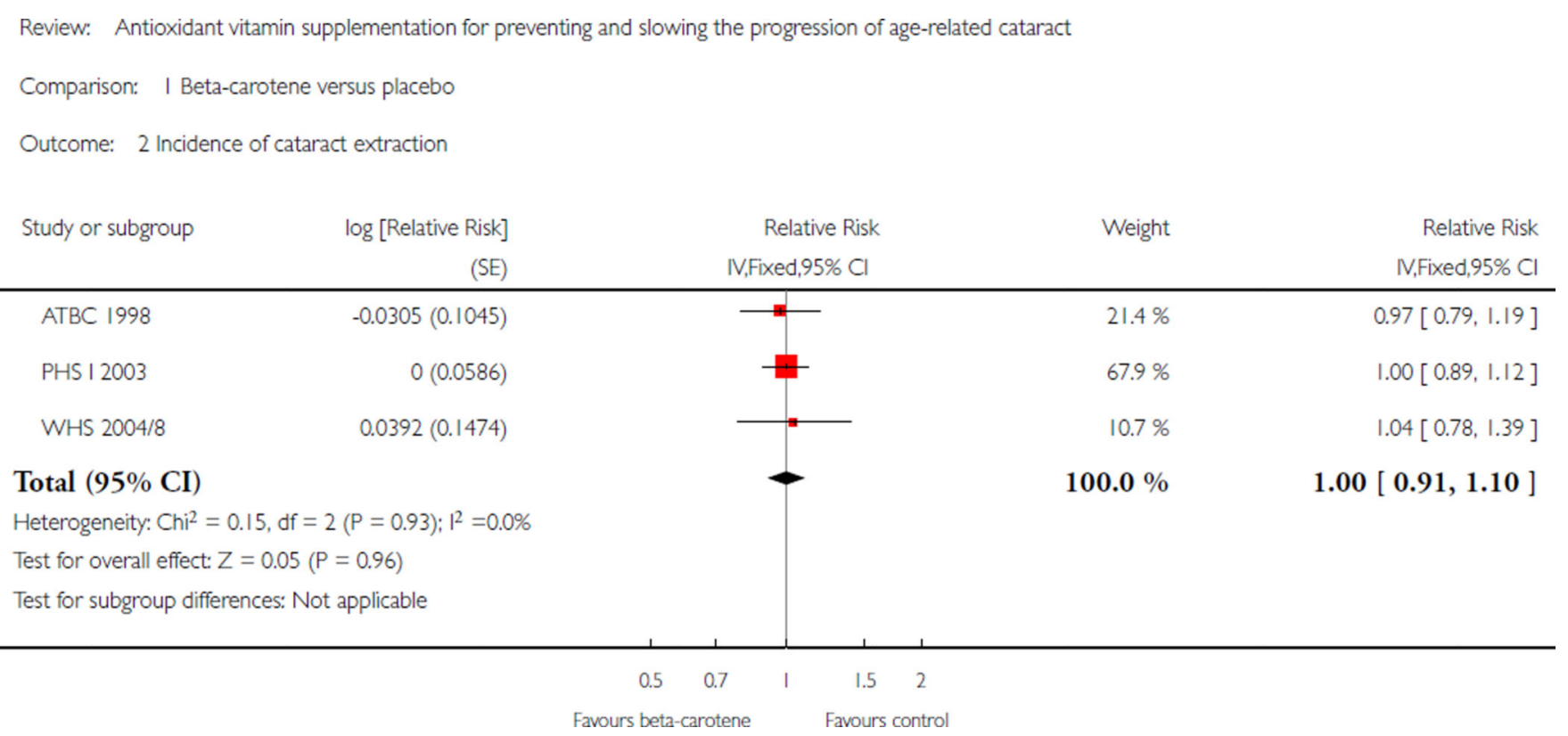

Analysis 1.2.

Comparison 1 Beta-carotene versus placebo, Outcome 2 Incidence of cataract extraction. 


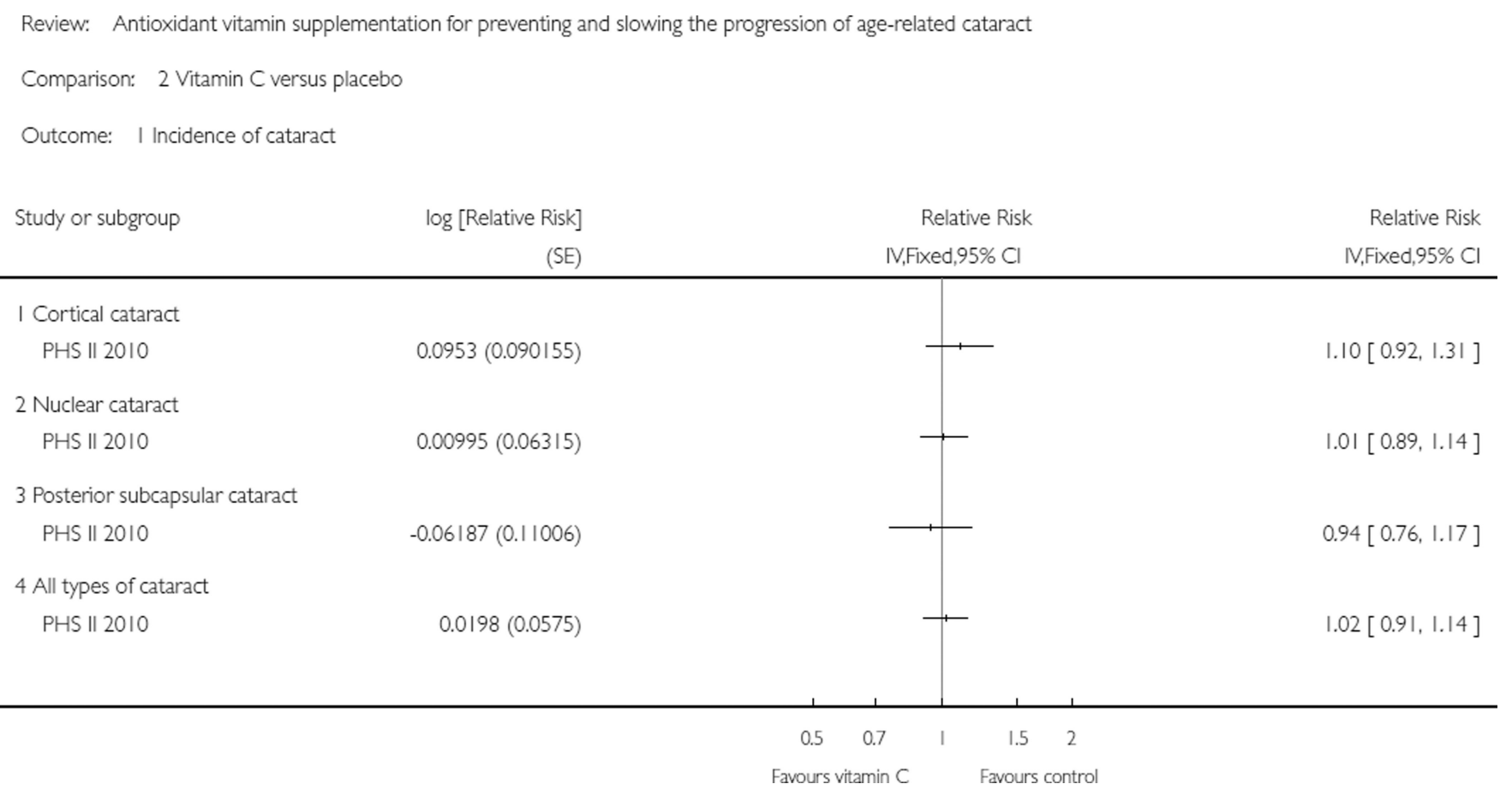

Analysis 2.1.

Comparison 2 Vitamin $\mathrm{C}$ versus placebo, Outcome 1 Incidence of cataract. 


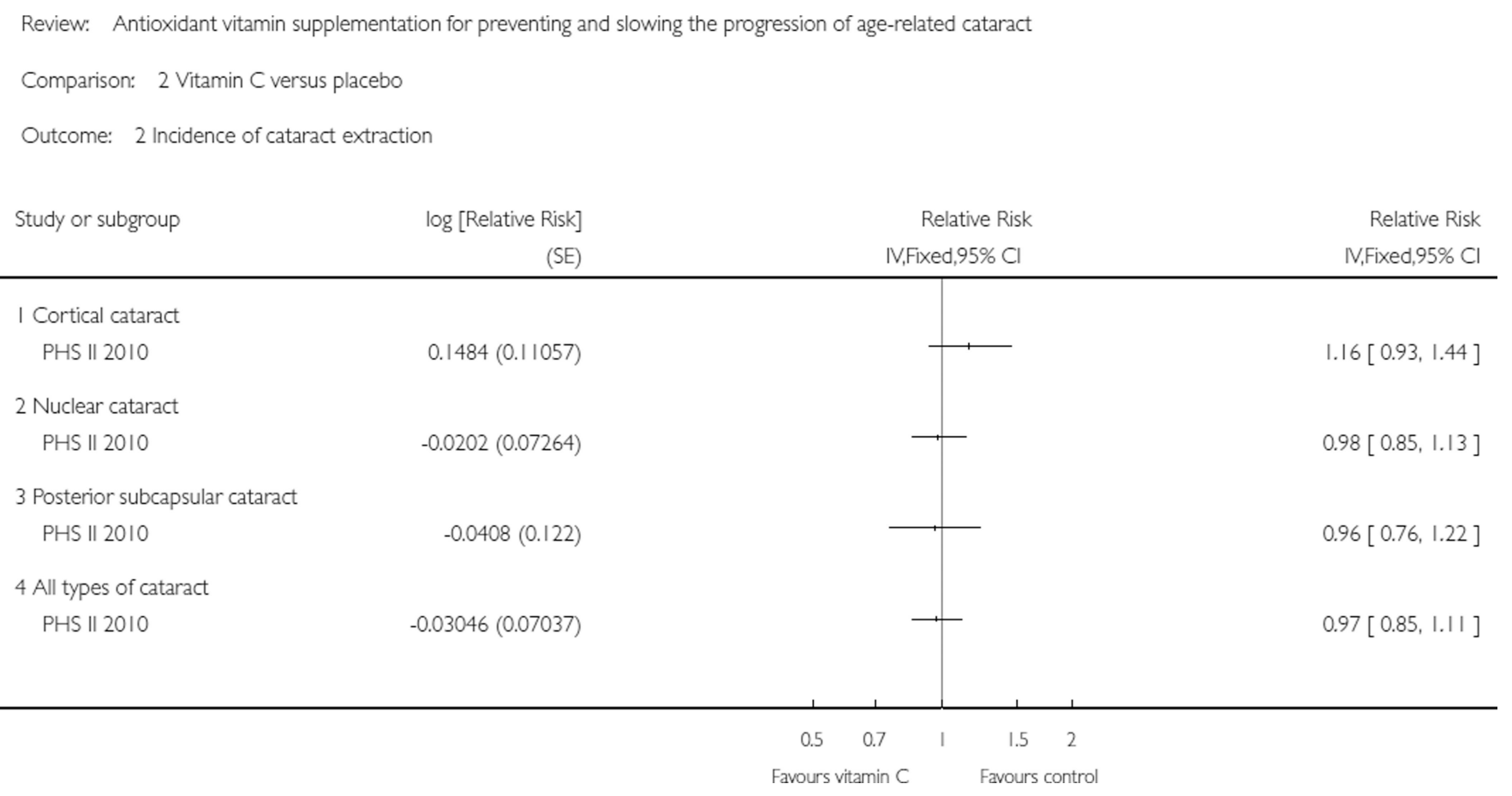

Analysis 2.2.

Comparison 2 Vitamin C versus placebo, Outcome 2 Incidence of cataract extraction. 


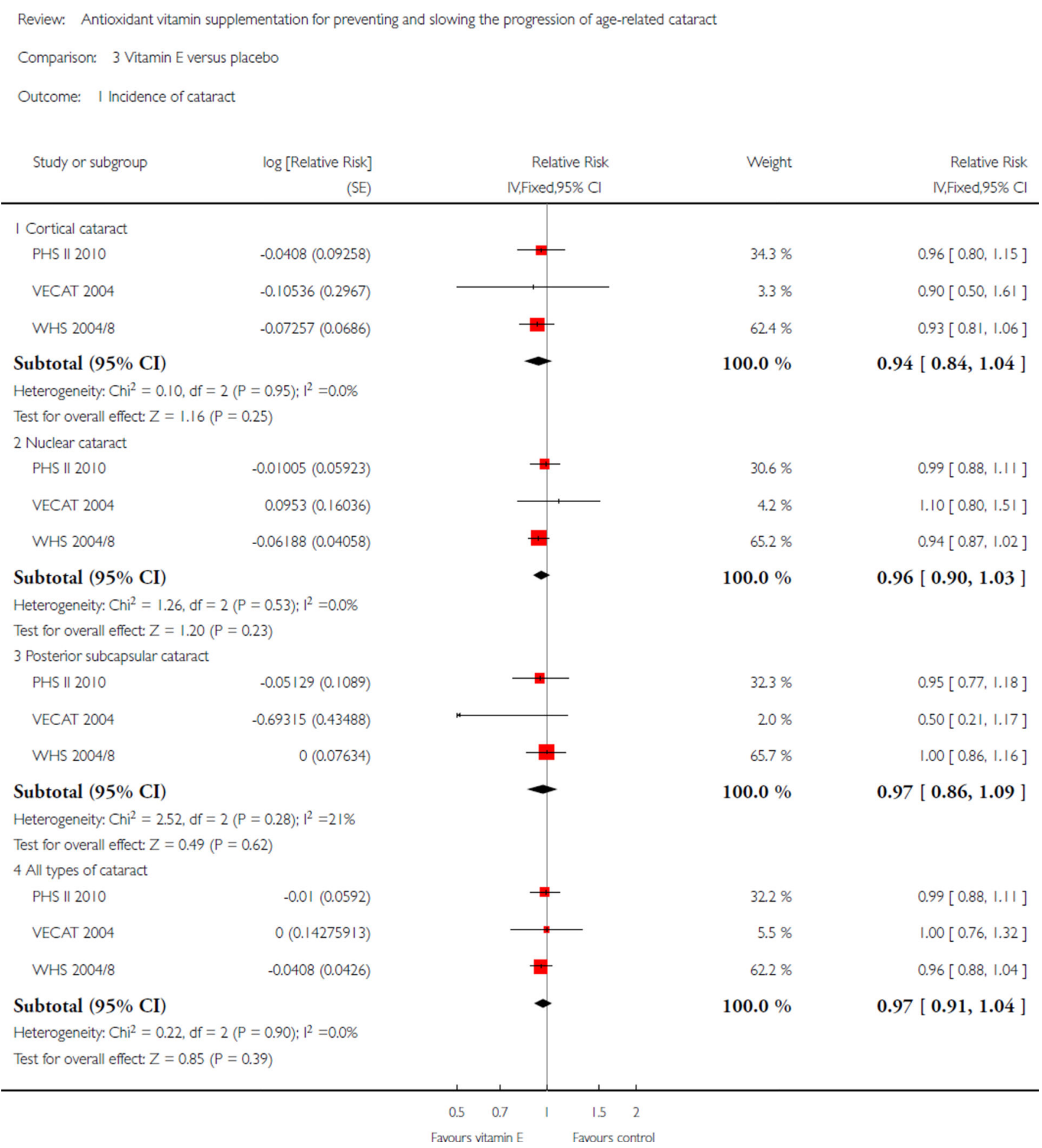

Analysis 3.1.

Comparison 3 Vitamin E versus placebo, Outcome 1 Incidence of cataract. 


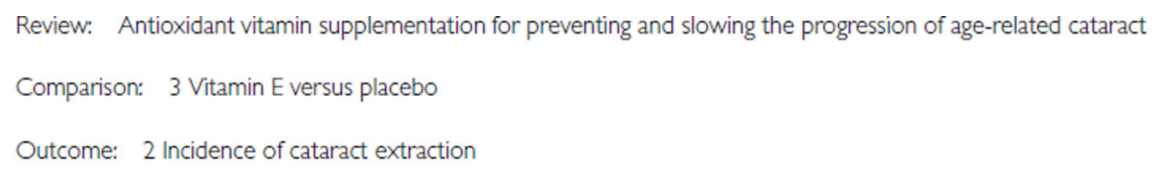

$34.9 \%$

$0.94[0.76,1.17]$

WHS 2004/8

$-0.0943(0.08064)$

\section{Subtotal $(95 \%$ CI $)$}

Heterogeneity: $\mathrm{Chi}^{2}=0.06, \mathrm{df}=\mathrm{I}(\mathrm{P}=0.8 \mathrm{I}) ; \mathrm{I}^{2}=0.0 \%$

Test for overall effect: $Z=1.28(P=0.20)$

2 Nuclear cataract

PHS II 2010

$-0.0408(0.07185)$

WHS 2004/8

$0(0.05119)$

\section{Subtotal $(95 \% \mathrm{CI})$}

Heterogeneity: $\mathrm{Chi}^{2}=0.2 \mathrm{I}, \mathrm{df}=\mathrm{I}(\mathrm{P}=0.64) ; \mathrm{I}^{2}=0.0 \%$

Test for overall effect: $Z=0.33(P=0.74)$

3 Posterior subcapsular cataract

PHS || 2010

$-0.0943(0.12166)$

WHS 2004/8

$0.06766(0.083)$

\section{Subtotal $(95 \% \mathrm{CI})$}

Heterogeneity: $\mathrm{Chi}^{2}=1.21, \mathrm{df}=\mathrm{I}(\mathrm{P}=0.27) ; \mathrm{I}^{2}=17 \%$

Test for overall effect: $Z=0.24(P=0.81)$

4 All types of cataract

ATBC 1998

$-0.0943(0.1034)$

PHS I| 2010

$-0.0408(0.07 \mid 85)$

PPP 2001

$0.0296(0.1768)$

VECAT 2004

$0.0861(0.233)$

WHS 2004/8

$0(0.0507)$

\section{Subtotal $(95 \%$ CI $)$}

Heterogeneity: $\mathrm{Chi}^{2}=1.04, \mathrm{df}=4(\mathrm{P}=0.90) ; \mathrm{I}^{2}=0.0 \%$

Test for overall effect: $Z=0.53(P=0.60)$

$65.1 \%$

$0.91[0.78,1.07]$

$100.0 \%$

$33.7 \%$

$66.3 \%$

$0.96[0.83,1.11]$

$1.00[0.90,1.11]$

$100.0 \%$

$0.99[0.91,1.07$ ]

$31.8 \%$

$68.2 \%$

$0.91[0.72,1.16]$

$1.07[0.91,1.26]$

$100.0 \%$

$1.02[0.89,1.16$ ]

$12.9 \%$

$0.91[0.74,1.11]$

$26.7 \%$

$4.4 \%$

$2.5 \%$

$53.5 \%$

$100.0 \%$

$0.98[0.91,1.05$ ]
$0.96[0.83,1.11]$

$1.03[0.73,1.46]$

$1.09[0.69,1.72]$

$1.00[0.91,1.10]$

Analysis 3.2.

Comparison 3 Vitamin E versus placebo, Outcome 2 Incidence of cataract extraction. 
Progression of cataract

\begin{tabular}{|c|c|c|c|c|}
\hline Study & Intervention & Duration & Outcome & Measure of effect \\
\hline \multicolumn{5}{|c|}{ Cortical cataract } \\
\hline VECAT 2004 & Vitamin E & Over 4 years & $\begin{array}{l}\text { Change in lens opacities using clinical } \\
\text { grading system }\end{array}$ & Risk ratio $0.9(95 \%$ CI 0.6 to 1.5$)$ \\
\hline \multicolumn{5}{|c|}{ Nuclear cataract } \\
\hline VECAT 2004 & Vitamin E & Over 4 years & $\begin{array}{l}\text { Change in lens opacities using clinical } \\
\text { grading system }\end{array}$ & Risk ratio 0.9 (95\% CI 0.7 to 1.3$)$ \\
\hline \multicolumn{5}{|c|}{ Posterior subcapsular cataract } \\
\hline VECAT 2004 & Vitamin E & Over 4 years & $\begin{array}{l}\text { Change in lens opacities using clinical } \\
\text { grading system }\end{array}$ & Risk ratio 2.5 (95\% CI 0.6 to 11.2$)$ \\
\hline \multicolumn{5}{|c|}{ All types of cataract } \\
\hline VECAT 2004 & Vitamin E & Over 4 years & $\begin{array}{l}\text { Change in lens opacities using clinical } \\
\text { grading system }\end{array}$ & Risk ratio 1.0 (95\% CI 0.7 to 1.3$)$ \\
\hline
\end{tabular}

Analysis 3.3.

Comparison 3 Vitamin E versus placebo, Outcome 3 Progression of cataract. 
Review: Antioxidant vitamin supplementation for preventing and slowing the progression of age-related cataract

Comparison: 4 Beta-carotene plus vitamin $E$ versus placebo

Outcome: I Incidence of cataract extraction

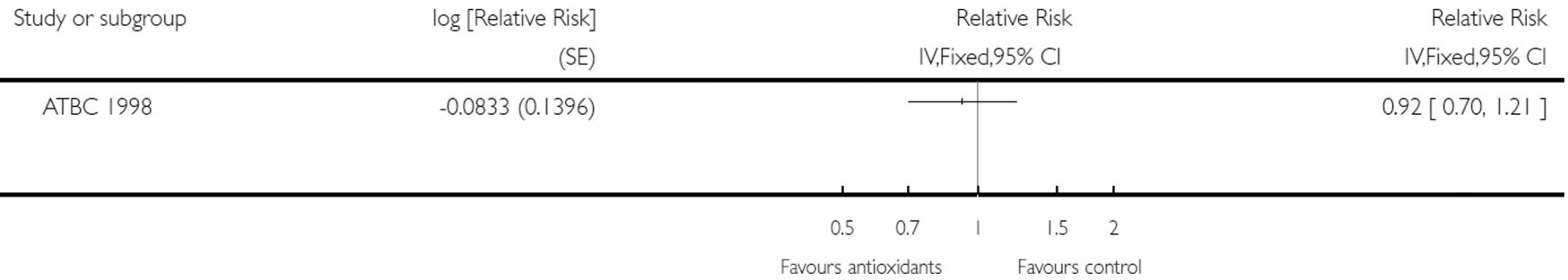

\section{Analysis 4.1.}

Comparison 4 Beta-carotene plus vitamin E versus placebo, Outcome 1 Incidence of cataract extraction. 


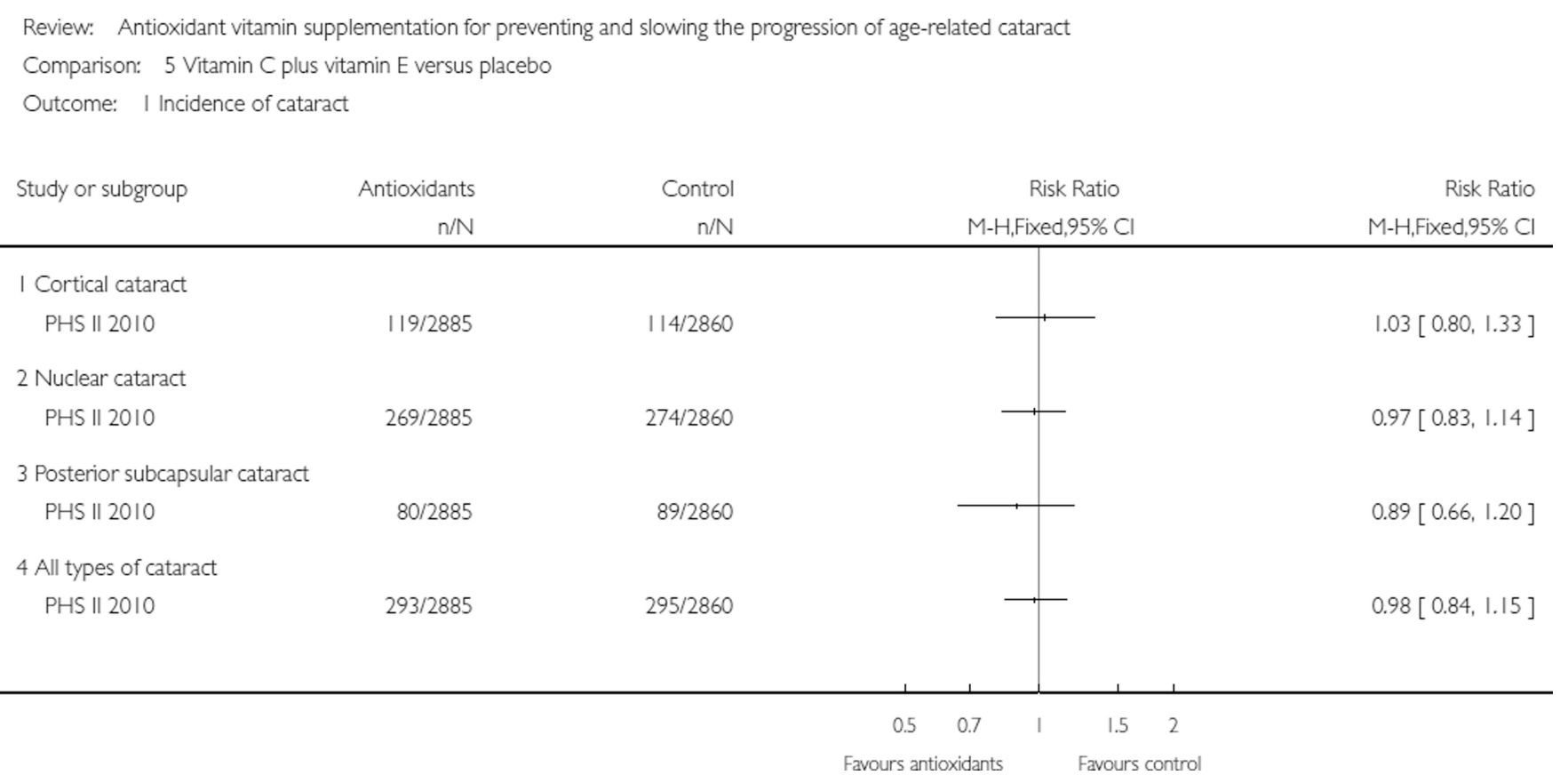

Analysis 5.1.

Comparison 5 Vitamin C plus vitamin E versus placebo, Outcome 1 Incidence of cataract. 
Review: Antioxidant vitamin supplementation for preventing and slowing the progression of age-related cataract

Comparison: 6 Beta-carotene plus vitamin $C$ plus vitamin $E$ versus placebo

Outcome: I Incidence of cataract extraction

Study or subgroup $\quad \log [$ Relative Risk]

Relative Risk

\section{Analysis 6.1.}

Comparison 6 Beta-carotene plus vitamin C plus vitamin E versus placebo, Outcome 1 Incidence of cataract extraction. 
Progression of cataract

\begin{tabular}{|c|c|c|c|c|}
\hline Study & Interventions & Duration & Outcomes & Measure of effect \\
\hline \multicolumn{5}{|c|}{ Cortical cataract } \\
\hline APC 2006 & $\begin{array}{l}\text { Beta-carotene + vitamin C } \\
\text { + vitamin E }\end{array}$ & 5 years & $\begin{array}{l}\text { Mean change ( } 95 \% \mathrm{CI}) \\
\text { per year in Lens Opaci- } \\
\text { ties Classification System } \\
\text { III (LOCS III) categories in } \\
\text { each group in right eye (left } \\
\text { eye results similar) }\end{array}$ & $\begin{array}{l}\text { Difference in slope be- } \\
\text { tween } 2 \text { groups by age: } \\
\text { Age group } 35 \text { to } 39:-0.001 \\
\text { ( } 95 \% \text { CI }-0.001 \text { to } 0.016 \text { ), } \\
\mathrm{P}=0.92 \\
\text { Age group } 40 \text { to } 44:-0.014 \\
\text { (95\% CI }-0.036 \text { to } 0.010 \text { ), } \\
\mathrm{P}=0.27 \\
\text { Age group } 45 \text { to } 50:-0.008 \\
(95 \% \mathrm{CI}-0.037 \text { to } 0.021) \text {, } \\
\mathrm{P}=0.57\end{array}$ \\
\hline AREDS 2001 & $\begin{array}{l}\text { Beta-carotene + vitamin C } \\
\text { + vitamin E }\end{array}$ & Mean of 6.3 years & $\begin{array}{l}\text { Cortical event from re- } \\
\text { peated measures logistic re- } \\
\text { gression }\end{array}$ & $\begin{array}{l}\text { Odds ratio } 0.99 \text { ( } 95 \% \mathrm{CI} \\
0.86 \text { to } 1.14)\end{array}$ \\
\hline REACT 2002 & $\begin{array}{l}\text { Beta-carotene + vitamin C } \\
\text { + vitamin E }\end{array}$ & $\begin{array}{l}\text { Over } 3 \text { years (among com- } \\
\text { pleters) }\end{array}$ & $\begin{array}{l}\text { Change from baseline } \\
\text { LOCS III cortical grade }\end{array}$ & $\begin{array}{l}\text { Antioxidant group: } 0.242 \\
(95 \% \mathrm{CI}+/-0.154) \\
\text { Placebo group: } 0.362 \\
(95 \% \mathrm{CI}+/-0.186), \mathrm{P}=0 . \\
309\end{array}$ \\
\hline \multicolumn{5}{|c|}{ Nuclear cataract } \\
\hline APC 2006 & $\begin{array}{l}\text { Beta-carotene + vitamin C } \\
\text { + vitamin E }\end{array}$ & 5 years & $\begin{array}{l}\text { Nuclear opalescence and } \\
\text { nuclear colour assessed as } \\
\text { mean change per year } \\
(95 \% \text { CI) in Lens Opac- } \\
\text { ities Classification System } \\
\text { III (LOCS III) categories in } \\
\text { each group in right eye (left } \\
\text { eye results similar) }\end{array}$ & 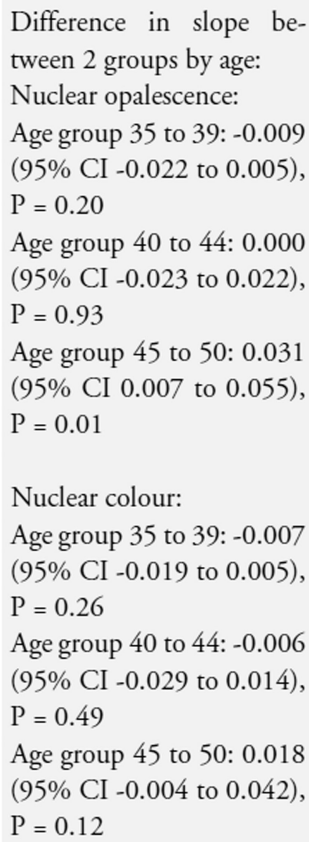 \\
\hline
\end{tabular}




\begin{tabular}{|c|c|c|c|c|}
\hline AREDS 2001 & $\begin{array}{l}\text { Beta-carotene + vitamin C } \\
\text { + vitamin E }\end{array}$ & Mean of 6.3 years & $\begin{array}{l}\text { Nuclear event from re- } \\
\text { peated measures logistic re- } \\
\text { gression }\end{array}$ & $\begin{array}{l}\text { Odds ratio: } 0.98(95 \% \mathrm{CI} \\
0.87 \text { to } 1.10)\end{array}$ \\
\hline REACT 2002 & $\begin{array}{l}\text { Beta-carotene + vitamin C } \\
\text { + vitamin E }\end{array}$ & Over 3 years & $\begin{array}{l}\text { Change from baseline: } \\
\text { LOCS nuclear grade }\end{array}$ & $\begin{array}{l}\text { Antioxidant group: } 0.564 \\
\text { (95\% CI +/- } 0.164) \\
\text { Placebo group: } 0.644 \\
(95 \% \mathrm{CI}+/-0.198), \mathrm{P}=0 . \\
347\end{array}$ \\
\hline
\end{tabular}

Posterior subcapsular cataract

\begin{tabular}{|c|c|c|c|c|}
\hline APC 2006 & $\begin{array}{l}\text { Beta-carotene + vitamin C } \\
\text { + vitamin E }\end{array}$ & 5 years & $\begin{array}{l}\text { Mean change per year } \\
(95 \% \text { CI) in Lens Opac- } \\
\text { ities Classification System } \\
\text { III (LOCS III) categories in } \\
\text { each group in right eye (left } \\
\text { eye results similar) }\end{array}$ & $\begin{array}{l}\text { Difference in slope be- } \\
\text { tween } 2 \text { groups by age: } \\
\text { Age group } 35 \text { to } 39:-0.002 \\
\text { ( } 95 \% \text { CI }-0.012 \text { to } 0.008 \text { ), } \\
P=0.68 \\
\text { Age group } 40 \text { to } 44: 0.005 \\
\text { (95\% CI }-0.021 \text { to } 0.031 \text { ), } \\
P=0.70 \\
\text { Age group } 45 \text { to } 50:-0.018 \\
(95 \% \text { CI }-0.043 \text { to } 0.023) \text {, } \\
P=0.08\end{array}$ \\
\hline AREDS 2001 & $\begin{array}{l}\text { Beta-carotene + vitamin C } \\
\text { + vitamin E }\end{array}$ & Mean of 6.3 years & $\begin{array}{l}\text { Posterior subcapsular event } \\
\text { from repeated measures lo- } \\
\text { gistic regression }\end{array}$ & $\begin{array}{l}\text { Odds ratio: } 0.94 \text { ( } 95 \% \mathrm{CI} \\
0.81 \text { to } 1.09)\end{array}$ \\
\hline REACT 2002 & $\begin{array}{l}\text { Beta-carotene + vitamin C } \\
\text { + vitamin E }\end{array}$ & Over 3 years & $\begin{array}{l}\text { Change from } \\
\text { baseline: LOCS III poste- } \\
\text { rior subcapsular grade }\end{array}$ & $\begin{array}{l}\text { Antioxidant group: } 0.248 \\
(95 \% \mathrm{CI}+/-0.120) \\
\text { Placebo group: } 0.314 \\
(95 \% \mathrm{CI}+/-0.207), \mathrm{P}=0 . \\
589\end{array}$ \\
\hline \multicolumn{5}{|c|}{ All types of cataract } \\
\hline AREDS 2001 & $\begin{array}{l}\text { Beta-carotene + vitamin C } \\
\text { + vitamin E }\end{array}$ & Mean of 6.3 years & $\begin{array}{l}\text { Any lens event (includes } \\
\text { cataract surgery) from re- } \\
\text { peated measures logistic re- } \\
\text { gression }\end{array}$ & $\begin{array}{l}\text { Odds ratio } 1.00 \text { ( } 95 \% \mathrm{CI} \\
0.90 \text { to } 1.11)\end{array}$ \\
\hline REACT 2002 & $\begin{array}{l}\text { Beta-carotene + vitamin C } \\
\text { + vitamin E }\end{array}$ & Over 3 years & $\begin{array}{l}\text { Retro data anterior: change } \\
\text { from baseline of } \% \text { pixels } \\
\text { opaque of lens images }\end{array}$ & $\begin{array}{l}\text { Antioxidant group: } 1.661 \\
(95 \% \mathrm{CI}+/-0.984) \\
\text { Placebo group: } 3.273 \\
(95 \% \mathrm{CI}+/-1.406), \mathrm{P}=0 . \\
048\end{array}$ \\
\hline
\end{tabular}

\section{Analysis 6.2.}

Comparison 6 Beta-carotene plus vitamin C plus vitamin E versus placebo, Outcome 2 Progression of cataract. 
Loss of visual acuity

\begin{tabular}{|c|c|c|c|c|}
\hline Study & Interventions & Duration & Outcomes & Measure of effect \\
\hline APC 2006 & $\begin{array}{l}\text { Beta-carotene + Vitamin C } \\
+ \text { Vitamin E }\end{array}$ & 5 years & $\begin{array}{l}\text { Change in best corrected visual } \\
\text { acuity at year } 5\end{array}$ & $\begin{array}{l}\text { Placebo group: } 1.66 \text { letters less } \\
\text { (SD 4.96) } \\
\text { Vitamin group: }-1.64 \text { letters less } \\
\text { (SD 4.74) } \mathrm{p}=0.8\end{array}$ \\
\hline AREDS 2001 & $\begin{array}{l}\text { Beta-carotene + Vitamin C } \\
+ \text { Vitamin E }\end{array}$ & 6.3 years & $\begin{array}{l}\text { Loss of visual acuity score of } 15 \\
\text { letters or more from baseline }\end{array}$ & $\begin{array}{l}\text { Odds ratio }=1.07(95 \% \text { CI: } 0.74- \\
1.54)\end{array}$ \\
\hline REACT 2002 & $\begin{array}{l}\text { Beta-carotene + Vitamin C } \\
+ \text { Vitamin E }\end{array}$ & Over 3 years & $\begin{array}{l}\text { Change in logarithm of Minimum } \\
\text { Angle of Resolution from baseline }\end{array}$ & $\begin{array}{l}\text { Antioxidant group: }-0.052(95 \% \\
\mathrm{CI}+/-0.027) \\
\text { Placebo group: }-0.073(95 \% \mathrm{CI}+/ \\
-0.034) \mathrm{p}=0.189\end{array}$ \\
\hline
\end{tabular}

Analysis 6.3.

Comparison 6 Beta-carotene plus vitamin C plus vitamin E versus placebo, Outcome 3 Loss of visual acuity. 


\section{Table 1}

Adverse events: hypercarotenodermia

\begin{tabular}{|l|l|l|l|l|}
\hline Study ID & Intervention & $\mathbf{n}(\boldsymbol{\%})$ & Control & $\mathbf{n}(\boldsymbol{\%})$ \\
\hline AREDS 2001 & Beta-carotene + vitamin C + vitamin E & $203(8.6 \%)$ & No antioxidants & $146(6.1 \%)$ \\
\hline ATBC 1998 & Beta-carotene + vitamin E & $1281(8.8 \%)$ & No antioxidants & $44(0.3 \%)$ \\
\hline REACT 2002 & Beta-carotene + vitamin C + vitamin E & $6(7.4 \%)$ & Placebo & $0(0 \%)$ \\
\hline PHS I 2003 & Beta-carotene & $1745(15.8 \%)$ & Placebo & $1535(13.9 \%)$ \\
\hline WHS 2004/8 & Beta-carotene & $2131(10.7 \%)$ & Placebo (includes vitamin E) & $1944(9.8 \%)$ \\
\hline
\end{tabular}




\title{
CHARACTERISTICS OF STUDIES
}

\author{
Characteristics of included studies [ordered by study ID]
}

\begin{tabular}{|c|c|c|}
\hline Methods & \multicolumn{2}{|c|}{$\begin{array}{l}\text { Design: multicenter, parallel-arm RCT } \\
\text { Method of randomization: in blocks of } 40 \\
\text { Method of allocation concealment: the placebo tablets were identical to active tablets in appearance and taste } \\
\text { Number randomized: } 798 \\
\text { Exclusions after randomization: none } \\
\text { Number analyzed: } 798 ; \text { Group } 1=398 \text {; Group } 2=400 \\
\text { Masking: participants, study workers, investigators, biostatistician masked } \\
\text { Losses to follow-up: equal across treatment groups (personal communication) } \\
\text { Unit of analysis: analysis conducted for each eye separately }\end{array}$} \\
\hline Participants & \multicolumn{2}{|c|}{$\begin{array}{l}\text { Country: India } \\
\text { Age: range: } 35 \text { to } 50 \text { years } \\
\text { Gender ( } \% \text { female): } 63.8 \% \text { in Group 1, 58.5\% in Group } 2 \\
\text { Inclusion criteria: age } 35 \text { to } 50 \text { years, best corrected visual acuity of 20/40 or better in both eyes } \\
\text { Exclusion criteria: diabetes mellitus, intraocular surgery, radiation therapy, steroid therapy, active use of vitamin } \\
\text { supplements, presence of congenital or traumatic cataract, active infectious keratitis, narrow anterior chamber angle }\end{array}$} \\
\hline Interventions & \multicolumn{2}{|c|}{$\begin{array}{l}\text { Treatment: vitamin C: } 500 \mathrm{mg} \text {; vitamin E: } 400 \mathrm{IU} \text {; beta-carotene: } 15 \mathrm{mg} 3 \text { times a week } \\
\text { Control: placebo } \\
\text { Duration of treatment/length of follow-up: } 5 \text { years }\end{array}$} \\
\hline Outcomes & \multicolumn{2}{|c|}{$\begin{array}{l}\text { Primary: } \\
\text { 1. Change in nuclear opalescence from baseline using Lens Opacities Classification System III } \\
\text { Secondary: } \\
\text { 1. Change from baseline of nuclear color } \\
\text { 2. Change from baseline of cortical cataract } \\
\text { 3. Change from baseline of posterior subscapular cataract } \\
\text { 4. Change from baseline of best corrected spectacle visual acuity } \\
\text { 5. Change from baseline of refraction } \\
\text { 6. Failure of treatment defined as cataract progression to a point necessitating surgery or best corrected visual acuity of } \\
\text { 20/400 or worse } \\
\text { 7. Cataract surgery was offered if best corrected visual acuity decreased to } 20 / 60 \text { or worse or if decreased visual acuity } \\
\text { caused problems with everyday functioning }\end{array}$} \\
\hline Notes & \multicolumn{2}{|c|}{$\begin{array}{l}\text { Study period: } 5 \text { years, } 1999 \text { to } 2004 \\
\text { Study population: majority were middle class or lower in rural South India } \\
\text { Subgroup analysis: results stratified by age } \\
\text { Control group event rate: continuous outcomes were used } \\
\text { Equivalence of baseline characteristics: important baseline characteristics appear equally distributed } \\
\text { Quality of life indicators: none reported } \\
\text { Funding: Francis I. Proctor Foundation, Aravind Eye Hospital, Peierls Foundation, Jack and DeLoris Lange Foundation, } \\
\text { Harper Inglis Trust }\end{array}$} \\
\hline \multicolumn{3}{|l|}{ Risk of bias } \\
\hline Bias & Authors' judgement & Support for judgement \\
\hline $\begin{array}{l}\text { Random } \\
\text { sequence } \\
\text { generation } \\
\text { (selection bias) }\end{array}$ & Low risk & $\begin{array}{l}\text { Randomization was completed in blocks of } 40 \text { and within this } \\
\text { group half were assigned to each treatment }\end{array}$ \\
\hline $\begin{array}{l}\text { Allocation } \\
\text { concealment } \\
\text { (selection bias) }\end{array}$ & Low risk & $\begin{array}{l}\text { The placebo tablets were identical to active tablets in } \\
\text { appearance and taste }\end{array}$ \\
\hline $\begin{array}{l}\text { Blinding } \\
\text { (performance } \\
\text { bias and } \\
\text { detection bias) } \\
\text { All outcomes }\end{array}$ & Low risk & $\begin{array}{l}\text { Participants, study workers, investigators, biostatistician were } \\
\text { masked }\end{array}$ \\
\hline $\begin{array}{l}\text { Incomplete } \\
\text { outcome data } \\
\text { (attrition bias) } \\
\text { All outcomes }\end{array}$ & Unclear risk & $\begin{array}{l}\text { Data on losses to follow-up were unavailable, but were } \\
\text { balanced across treatment groups }\end{array}$ \\
\hline
\end{tabular}

Cochrane Database Syst Rev. Author manuscript; available in PMC 2015 April 27. 


\begin{tabular}{|c|c|c|}
\hline $\begin{array}{l}\text { Selective } \\
\text { reporting } \\
\text { (reporting bias) }\end{array}$ & Low risk & $\begin{array}{l}\text { Results were reported for outcomes described in the methods } \\
\text { section }\end{array}$ \\
\hline Other bias & Low risk & Met other parameters of quality that were assessed (see text) \\
\hline \multicolumn{3}{|l|}{ AREDS 2001} \\
\hline Methods & \multicolumn{2}{|c|}{$\begin{array}{l}\text { Design: multicenter, parallel-arm RCT } \\
\text { Method of randomization: computer-generated list (AREDS2 Advantage Electronic } \\
\text { Data Capture system (AdvantageEDCSM)). } \\
\text { Method of allocation concealment: the study tablets were identical in external and internal } \\
\text { appearance and taste } \\
\text { Number randomized: } 4757 \\
\text { Exclusions after randomization: } 128 \\
\text { Number analyzed: } 4629 \text {; antioxidants }=2304 \text {; no antioxidants }=2325 \\
\text { Masking: participants, care providers and outcomes assessors masked } \\
\text { Losses to follow-up: } 15 \% \text { (includes those lost to follow-up and current smokers who } \\
\text { withdrew from the study) } \\
\text { Unit of analysis: individuals }\end{array}$} \\
\hline Participants & \multicolumn{2}{|c|}{$\begin{array}{l}\text { Country: USA } \\
\text { Age: median: } 68 \text { years; range: } 55 \text { to } 80 \text { years } \\
\text { Gender ( } \% \text { female): } 56 \% \\
\text { Inclusion criteria: best corrected visual acuity of } 20 / 32 \text { or better in at least one eye, at least one eye was free from eye } \\
\text { disease that could complicate assessment of age-related macular degeneration, lens opacity progression or visual acuity } \\
\text { Exclusion criteria: illness or disorders such as history of cancer with a poor 7-year prognosis, major cardiovascular or } \\
\text { cerebrovascular event within the last year or hemochromatosis }\end{array}$} \\
\hline Interventions & \multicolumn{2}{|c|}{$\begin{array}{l}\text { Treatment: vitamin C: } 500 \mathrm{mg} \text {; vitamin E: } 400 \mathrm{IU} \text {; beta-carotene: } 15 \mathrm{mg} \text { daily } 58 \%(\mathrm{n}=853) \text { of those in the antioxidant } \\
\text { group also received } 80 \mathrm{mg} \text { of Zinc } \\
\text { Control: placebo } \\
\text { Duration of treatment/length of follow-up: average } 6.3 \text { years }\end{array}$} \\
\hline Outcomes & \multicolumn{2}{|c|}{$\begin{array}{l}\text { 1. Incidence of a cortical, nuclear or posterior subcapsular event } \\
\text { 2. Incidence of any lens event } \\
\text { 3. Best-corrected visual acuity } \\
\text { 4. Incidence of cataract surgery } \\
\text { 5. Incidence of any severe lens event } \\
\text { Outcomes were assessed at } 6 \text { months and annually } \\
\text { Some participants had } 1 \text { eye enrolled in the study and others had } 2 \text { study eyes }\end{array}$} \\
\hline Notes & \multicolumn{2}{|c|}{$\begin{array}{l}\text { Study period: } 1992 \text { to } 2001 \\
\text { Study population: apparently well-nourished older cohort } \\
\text { Subgroup analysis: (a) on eyes with no or minimal opacity in one eye }(\mathrm{n}=823) \text {, (b) no opacity in both eyes }(\mathrm{n}=338) \text { at } \\
\text { baseline, (c) by type of cataract } \\
\text { Control group event rate: } 34 \% \text { for any lens event over } 5 \text { years } \\
\text { Equivalence of baseline characteristics: important baseline characteristics appear equally distributed. Approximately, } 66 \% \\
\text { of AREDS participants chose to take CENTRUM, a commercially available multivitamin-mineral supplement, the use was } \\
\text { balanced across treatment groups } \\
\text { Quality of life indicators: reported } \\
\text { Funding: National Eye Institute, National Institutes of Health, USA and Bausch and Lomb Inc }\end{array}$} \\
\hline \multicolumn{3}{|l|}{ Risk of bias } \\
\hline Bias & Authors' judgement & Support for judgement \\
\hline $\begin{array}{l}\text { Random } \\
\text { sequence } \\
\text { generation } \\
\text { (selection bias) }\end{array}$ & Low risk & Computer-generated list \\
\hline $\begin{array}{l}\text { Allocation } \\
\text { concealment } \\
\text { (selection bias) }\end{array}$ & Low risk & $\begin{array}{l}\text { The study tablets were identical in external and internal } \\
\text { appearance and taste }\end{array}$ \\
\hline $\begin{array}{l}\text { Blinding } \\
\text { (performance } \\
\text { bias and } \\
\text { detection bias) } \\
\text { All outcomes }\end{array}$ & Low risk & $\begin{array}{l}\text { Participants, care providers and outcomes assessors were } \\
\text { masked }\end{array}$ \\
\hline $\begin{array}{l}\text { Incomplete } \\
\text { outcome data } \\
\text { (attrition bias) } \\
\text { All outcomes }\end{array}$ & Low risk & $\begin{array}{l}90 \% \text { had at least five years of follow-up. The losses to follow- } \\
\text { up were balanced across treatment groups }\end{array}$ \\
\hline
\end{tabular}




\begin{tabular}{|c|c|c|}
\hline $\begin{array}{l}\text { Selective } \\
\text { reporting } \\
\text { (reporting bias) }\end{array}$ & Low risk & $\begin{array}{l}\text { Results were reported for outcomes described in the methods } \\
\text { section }\end{array}$ \\
\hline Other bias & Low risk & Met other parameters of quality that were assessed (see text) \\
\hline \multicolumn{3}{|l|}{ АТВС 1998} \\
\hline Methods & \multicolumn{2}{|c|}{$\begin{array}{l}\text { Design: } 2 \times 2 \text { factorial RCT } \\
\text { Method of randomization: unavailable } \\
\text { Method of allocation concealment: unavailable } \\
\text { Number randomized: } 29,133 \\
\text { Exclusions after randomization: } 199 \\
\text { Number analyzed: } 28,934 \\
\text { Masking: participants, care providers and outcomes assessors masked } \\
\text { Losses to follow-up: } 28.4 \% \text { in the alpha-tocopherol alone group to } 29.4 \% \text { in the beta-carotene alone group } \\
\text { Unit of analysis: individuals }\end{array}$} \\
\hline Participants & \multicolumn{2}{|c|}{$\begin{array}{l}\text { Country: Finland } \\
\text { Age: median: } 57 \text { years; range: } 50 \text { to } 69 \text { years } \\
\text { Gender: all men } \\
\text { Inclusion criteria: smokers of at least } 5 \text { cigarettes per day, absence of lung cancer as determined by an X-ray } \\
\text { Exclusion criteria: those with a history of cancer or serious disease limiting the ability to participate, those taking } \\
\text { supplements of vitamin E, vitamin A or beta-carotene in excess of predefined doses, those on treatment with anticoagulants }\end{array}$} \\
\hline Interventions & \multicolumn{2}{|c|}{$\begin{array}{l}\text { Treatment: } \\
\text { (a) Alpha-tocopherol: } 50 \mathrm{mg} \text { once daily } \\
\text { (b) Beta-carotene: } 20 \mathrm{mg} \text { once daily } \\
\text { (c) Combination: once daily } \\
\text { Control: placebo } \\
\text { Duration of treatment/length of follow-up: } 5 \text { to } 8 \text { years; median: } 5.7 \text { years; } 1,59,199 \text { person-years }\end{array}$} \\
\hline Outcomes & \multicolumn{2}{|c|}{$\begin{array}{l}\text { 1. Incidence of cataract extraction } \\
\text { Outcome was identified from the National Hospital Discharge Registry using International Classification of Diseases codes }\end{array}$} \\
\hline Notes & \multicolumn{2}{|c|}{$\begin{array}{l}\text { Study period: } 1986 \text { to } 1992 \\
\text { Study population: apparently healthy male smokers over } 50 \text { years } \\
\text { Subgroup analysis: age } \\
\text { Control group event rate: } 1.44 \% \text { over a median period of } 5.7 \text { years } \\
\text { Equivalence of baseline characteristics: important baseline characteristics appear equal. } \\
\text { There were fewer participants with diabetes in the placebo group } \\
\text { Quality of life indicators: none reported } \\
\text { Funding: National Public Health Institute of Finland and National Cancer Institute, National Institutes of Health, USA } \\
\text { Cataract extraction rates may differ by type of cataract, e.g. Posterior Subcapsular Cataract is treated early because of early } \\
\text { decrease in vision }\end{array}$} \\
\hline \multicolumn{3}{|l|}{ Risk of bias } \\
\hline Bias & Authors' judgement & Support for judgement \\
\hline $\begin{array}{l}\text { Random } \\
\text { sequence } \\
\text { generation } \\
\text { (selection bias) }\end{array}$ & Unclear risk & Information unavailable \\
\hline $\begin{array}{l}\text { Allocation } \\
\text { concealment } \\
\text { (selection bias) }\end{array}$ & Unclear risk & Information unavailable \\
\hline $\begin{array}{l}\text { Blinding } \\
\text { (performance } \\
\text { bias and } \\
\text { detection bias) } \\
\text { All outcomes }\end{array}$ & Low risk & $\begin{array}{l}\text { Participants, care providers and outcomes assessors were } \\
\text { masked }\end{array}$ \\
\hline $\begin{array}{l}\text { Incomplete } \\
\text { outcome data } \\
\text { (attrition bias) } \\
\text { All outcomes }\end{array}$ & Unclear risk & $\begin{array}{l}\text { Losses to follow-up were greater than } 28 \% \text {, but were roughly } \\
\text { equal across treatment groups }\end{array}$ \\
\hline $\begin{array}{l}\text { Selective } \\
\text { reporting } \\
\text { (reporting bias) }\end{array}$ & Low risk & $\begin{array}{l}\text { Results were reported for outcomes described in the methods } \\
\text { section }\end{array}$ \\
\hline Other bias & Low risk & Met other parameters of quality that were assessed (see text) \\
\hline
\end{tabular}




\begin{tabular}{|c|c|c|}
\hline Methods & \multicolumn{2}{|c|}{$\begin{array}{l}\text { Design: } 2 \times 2 \text { factorial RCT } \\
\text { Method of randomization: computer-generated list of random numbers } \\
\text { Method of allocation concealment: study pills in the treatment arms were identical except for the active agent in the beta- } \\
\text { carotene group } \\
\text { Number randomized: } 22,071 \\
\text { Exclusions after randomization: } 1103 \text {; aspirin and beta-carotene: } 286 \text {, aspirin and placebo: } 278 \text {, beta-carotene and placebo } \\
275 \text {, placebo only: } 264 \\
\text { Number analyzed: } 20,968 \text {; aspirin and beta-carotene }=5231 \text {, aspirin and placebo }=5242 \text {, beta-carotene and placebo }= \\
\text { 5244, placebo only }=5251 \\
\text { Masking: participants, care providers and outcomes assessors masked } \\
\text { Losses to follow-up: } 99.2 \% \text { provided information on morbidity after } 11 \text { years } \\
\text { Unit of analysis: individuals }\end{array}$} \\
\hline Participants & \multicolumn{2}{|c|}{$\begin{array}{l}\text { Country: USA } \\
\text { Age: mean: } 52.6 \text { years; range: } 40 \text { to } 84 \text { years } \\
\text { Gender: all male } \\
\text { Inclusion criteria: no history of cancer (except non-melanoma skin cancer), myocardial infarction, stroke or transient } \\
\text { cerebral ischemia } \\
\text { Exclusion criteria: current use of vitamin A supplement }\end{array}$} \\
\hline Interventions & \multicolumn{2}{|c|}{$\begin{array}{l}\text { Treatment: } \\
\text { (a) Beta-carotene: } 50 \mathrm{mg} \text { on alternate days } \\
\text { (b) Aspirin: } 325 \mathrm{mg} \text { on alternate days } \\
\text { Control: placebo, aspirin } \\
\text { Duration of treatment/length of follow-up: } 12 \text { years; range: } 11.6 \text { to } 14.2 \text { years }\end{array}$} \\
\hline Outcomes & \multicolumn{2}{|c|}{$\begin{array}{l}\text { 1. Incidence of age-related cataract over } 12 \text { years } \\
\text { 2. Extraction of age-related cataract over } 12 \text { years } \\
\text { Outcome assessment was based on self reports confirmed by medical record review } \\
\text { Outcome assessed in the worse eye is used in the analysis }\end{array}$} \\
\hline Notes & \multicolumn{2}{|c|}{$\begin{array}{l}\text { Study period: } 1982 \text { to } 1995 \\
\text { Study population: apparently healthy male medical professionals over } 40 \text { years } \\
\text { Subgroup analysis: (a) age (b) baseline smoking status } \\
\text { Control group event rate: } 9.7 \% \text { over } 12 \text { years for incident cataract } \\
\text { Equivalence of baseline characteristics: important baseline characteristics appear equally distributed } \\
\text { Quality of life indicators: none reported } \\
\text { Funding: National Institutes of Health, USA }\end{array}$} \\
\hline \multicolumn{3}{|l|}{ Risk of bias } \\
\hline Bias & Authors' judgement & Support for judgement \\
\hline $\begin{array}{l}\text { Random } \\
\text { sequence } \\
\text { generation } \\
\text { (selection bias) }\end{array}$ & Low risk & Computer-generated list of random numbers \\
\hline $\begin{array}{l}\text { Allocation } \\
\text { concealment } \\
\text { (selection bias) }\end{array}$ & Low risk & $\begin{array}{l}\text { Study pills in the treatment arms were identical except for the } \\
\text { active agent in the beta-carotene group }\end{array}$ \\
\hline $\begin{array}{l}\text { Blinding } \\
\text { (performance } \\
\text { bias and } \\
\text { detection bias) } \\
\text { All outcomes }\end{array}$ & Low risk & Participants, care providers and outcomes assessors masked \\
\hline $\begin{array}{l}\text { Incomplete } \\
\text { outcome data } \\
\text { (attrition bias) } \\
\text { All outcomes }\end{array}$ & Low risk & $\begin{array}{l}\text { Morbidity follow-up rate was } 99.2 \% \text { and balanced across } \\
\text { treatment groups }\end{array}$ \\
\hline $\begin{array}{l}\text { Selective } \\
\text { reporting } \\
\text { (reporting bias) }\end{array}$ & Low risk & $\begin{array}{l}\text { Results were reported for outcomes described in the methods } \\
\text { section }\end{array}$ \\
\hline Other bias & Low risk & Met other parameters of quality that were assessed (see text) \\
\hline \multicolumn{3}{|l|}{ PHS II 2010} \\
\hline Methods & \multicolumn{2}{|c|}{$\begin{array}{l}\text { Design: } 2 \times 2 \times 2 \times 2 \text { factorial RCT } \\
\text { Method of randomization: computer-generated list of random numbers } \\
\text { Method of allocation concealment: study pills in the treatment arms were identical } \\
\text { Number randomized: } 14,641 \\
\text { Exclusions after randomization: } 3096 \text {; vitamin C and vitamin E: } 771 \text {, vitamin C: } 759 \text {, vitamin E: } 773 \text {, placebo: } 793 \\
\text { Number analyzed: } 11,545 \text {; vitamin C and vitamin E: } 2885 \text {, vitamin C: } 2914 \text {, vitamin E: } 2886 \text {, placebo: } 2860\end{array}$} \\
\hline
\end{tabular}

Cochrane Database Syst Rev. Author manuscript; available in PMC 2015 April 27. 


\begin{tabular}{l|l} 
& $\begin{array}{l}\text { Masking: participants, care providers and outcomes assessors masked } \\
\text { Losses to follow-up: 95.3\% for morbidity and 97.7\% for mortality } \\
\text { Unit of analysis: individuals }\end{array}$ \\
\hline Participants & $\begin{array}{l}\text { Country: USA } \\
\text { Age: mean: 62 years, standard deviation: } 7.9 \\
\text { Gender: all male } \\
\text { Inclusion criteria: no history of cancer (except non-melanoma skin cancer), cardiovascular disease, current liver disease, } \\
\text { renal disease, peptic ulcer or gout } \\
\text { Exclusion criteria: unwillingness to avoid use of non-study supplements }\end{array}$ \\
\hline Interventions & $\begin{array}{l}\text { Treatment: } \\
\text { (a) Vitamin C: } 500 \text { mg daily } \\
\text { (b) Vitamin E: 400 IU on alternate days } \\
\text { Control: placebo, vitamin C, vitamin E } \\
\text { Duration of treatment/length of follow-up: mean: 8 years }\end{array}$ \\
\hline Outcomes & $\begin{array}{l}\text { 1. Incidence of age-related cataract over 12 years } \\
\text { 2. Extraction of age-related cataract over 12 years } \\
\text { Outcome assessment was based on self reports confirmed by medical record review } \\
\text { Outcome assessed in the worse eye is used in the analysis }\end{array}$ \\
\hline Notes & $\begin{array}{l}\text { Study period: } 1997 \text { to 2007 } \\
\text { Study population: apparently healthy male medical professionals over } 50 \text { years } \\
\text { Subgroup analysis: (a) age (b) type of cataract and possible risk factors } \\
\text { Control group event rate: vitamin C: 10.1\%, vitamin E: 10.3\% over 8 years for incident cataract } \\
\text { Equivalence of baseline characteristics: important baseline characteristics appear equally distributed } \\
\text { Quality of life indicators: none reported } \\
\text { Funding: National Institutes of Health, USA, BASF Corporation }\end{array}$ \\
\hline
\end{tabular}

\begin{tabular}{|c|c|c|}
\hline \multicolumn{3}{|l|}{ Risk of bias } \\
\hline Bias & Authors' judgement & Support for judgement \\
\hline $\begin{array}{l}\text { Random } \\
\text { sequence } \\
\text { generation } \\
\text { (selection bias) }\end{array}$ & Low risk & Computer-generated list of random numbers \\
\hline $\begin{array}{l}\text { Allocation } \\
\text { concealment } \\
\text { (selection bias) }\end{array}$ & Low risk & Study pills in the treatment arms were identical \\
\hline $\begin{array}{l}\text { Blinding } \\
\text { (performance } \\
\text { bias and } \\
\text { detection bias) } \\
\text { All outcomes }\end{array}$ & Low risk & Participants, care providers and outcome assessors masked \\
\hline $\begin{array}{l}\text { Incomplete } \\
\text { outcome data } \\
\text { (attrition bias) } \\
\text { All outcomes }\end{array}$ & Low risk & $\begin{array}{l}\text { Morbidity follow-up rate was } 95.3 \% \text { and balanced across } \\
\text { treatment groups }\end{array}$ \\
\hline $\begin{array}{l}\text { Selective } \\
\text { reporting } \\
\text { (reporting bias) }\end{array}$ & Low risk & $\begin{array}{l}\text { Results were reported for outcomes described in the methods } \\
\text { section }\end{array}$ \\
\hline Other bias & Low risk & Met other parameters of quality that were assessed (see text) \\
\hline \multicolumn{3}{|l|}{ PPP 2001} \\
\hline Methods & \multicolumn{2}{|c|}{$\begin{array}{l}\text { Design: } 2 \times 2 \text { factorial RCT } \\
\text { Method of randomization: computer-generated randomization table } \\
\text { Method of allocation concealment: treatments were centrally assigned on telephone verification of the correctness of } \\
\text { inclusion criteria with a separate computer-generated randomization table produced for each physician in random permuted } \\
\text { blocks of } 12 \\
\text { Number randomized: } 4495 \\
\text { Exclusions post randomization: none } \\
\text { Number analyzed: } 4495 \\
\text { Masking: open label trial. Clinical events were validated by an expert committee masked to treatment assignment, unclear } \\
\text { if it extended to the outcome of interest in this review } \\
\text { Losses to follow-up: vitamin E group: } 14 \text {, placebo group: } 17 \\
\text { Unit of analysis: individuals }\end{array}$} \\
\hline Participants & \multicolumn{2}{|c|}{$\begin{array}{l}\text { Country: Italy } \\
\text { Age: mean: } 64.5 \text {, standard deviation: } 7.6-7.7 \\
\text { Gender: both male and female }\end{array}$} \\
\hline
\end{tabular}

Cochrane Database Syst Rev. Author manuscript; available in PMC 2015 April 27. 


\begin{tabular}{l|l} 
& $\begin{array}{l}\text { Inclusion criteria: age over } 50 \text { years with at least one of the major cardiovascular risk factors } \\
\text { Exclusion criteria: treatment with anti-platelet drugs, anti-inflammatory agents or anticoagulants, those with diseases with } \\
\text { poor short-term prognosis }\end{array}$ \\
\hline Interventions & $\begin{array}{l}\text { Treatment: vitamin E: } 300 \mathrm{mg} \text { daily } \\
\text { Control: placebo } \\
\text { Duration of treatment/length of follow-up: mean of } 3.6 \text { years }\end{array}$ \\
\hline Outcomes & $\begin{array}{l}\text { 1. Incidence of cataract surgery } \\
\text { Outcome assessment was validated by chart review }\end{array}$ \\
\hline Notes & $\begin{array}{l}\text { Study period: } 1993 \text { to } 1998 \\
\text { Study population: individuals with at least one risk factor for cardiovascular disease } \\
\text { Subgroup analysis: none } \\
\text { Control group event rate: } 2.7 \% \\
\text { Equivalence of baseline characteristics: important baseline characteristics appear equally distributed } \\
\text { Quality of life indicators: none reported } \\
\text { Funding: public source }\end{array}$ \\
\hline Risk of bias
\end{tabular}

\begin{tabular}{|c|c|c|}
\hline Bias & Authors' judgement & Support for judgement \\
\hline $\begin{array}{l}\text { Random } \\
\text { sequence } \\
\text { generation } \\
\text { (selection bias) }\end{array}$ & Low risk & Computer-generated list of random numbers \\
\hline $\begin{array}{l}\text { Allocation } \\
\text { concealment } \\
\text { (selection bias) }\end{array}$ & Low risk & Treatments were centrally assigned \\
\hline $\begin{array}{l}\text { Blinding } \\
\text { (performance } \\
\text { bias and } \\
\text { detection bias) } \\
\text { All outcomes }\end{array}$ & Unclear risk & Open-label trial \\
\hline $\begin{array}{l}\text { Incomplete } \\
\text { outcome data } \\
\text { (attrition bias) } \\
\text { All outcomes }\end{array}$ & Low risk & $\begin{array}{l}\text { Losses to follow-up were } 0.6 \% \text { and } 0.75 \% \text { in the treatment and } \\
\text { placebo groups }\end{array}$ \\
\hline $\begin{array}{l}\text { Selective } \\
\text { reporting } \\
\text { (reporting bias) }\end{array}$ & Low risk & $\begin{array}{l}\text { Results were reported for outcomes described in the methods } \\
\text { section }\end{array}$ \\
\hline Other bias & Low risk & $\begin{array}{l}\text { More than } 13 \% \text { of those randomized to vitamin E discontinued } \\
\text { the medication, which is likely to bias the results towards no } \\
\text { effect }\end{array}$ \\
\hline \multicolumn{3}{|l|}{ REACT 2002} \\
\hline Methods & \multicolumn{2}{|c|}{$\begin{array}{l}\text { Design: multicenter, parallel-arm RCT } \\
\text { Method of randomization: Efron's biased coin method } \\
\text { Method of allocation concealment: those involved in preparing the randomization scheme were not associated with } \\
\text { determining eligibility, administering the intervention or assessing the outcomes } \\
\text { Number randomized: } 297 \\
\text { Exclusions after randomization: none (see number analyzed and losses to follow-up) } \\
\text { Number analyzed: completers of the study at } 3 \text { years: antioxidants }=81 \text {; placebo }=77 \\
\text { Masking: participants, care providers and outcomes assessors masked } \\
\text { Losses to follow-up: } 66(22 \%) \text { after two years, } 139(47 \%) \text { after } 3 \text { years, } 261(88 \%) \text { after } 4 \text { years } \\
\text { Unit of analysis: individuals }\end{array}$} \\
\hline Participants & \multicolumn{2}{|c|}{$\begin{array}{l}\text { Country: USA and UK } \\
\text { Age: USA: mean: } 64.7 \text { years, standard deviation: } 9.1 \text { years, UK: mean: } 67.9 \text { years, standard deviation: } 8.5 \text { years } \\
\text { Gender ( } \% \text { female): USA: } 62.4 \% \text {, UK: } 55.7 \% \\
\text { Inclusion criteria: age, } 40 \text { years or older, at least at eye satisfying the following criteria: cataract extraction unlikely within } \\
\text { the next } 2 \text { years, immature idiopathic senile cataract present in at least one or both eyes, logMAR acuity }<=0.5 \text {, no } \\
\text { clinical signs of glaucoma } \\
\text { Exclusion criteria: use of vitamin supplements }\end{array}$} \\
\hline
\end{tabular}




\begin{tabular}{|c|c|c|}
\hline Interventions & \multicolumn{2}{|c|}{$\begin{array}{l}\text { Treatment: } \\
\text { Beta-carotene: } 6 \mathrm{mg} \text {; vitamin C: } 250 \mathrm{mg} \text {; all-rac alpha-tocopherol acetate: } 200 \mathrm{mg} \text { capsules } 3 \text { times per day } \\
\text { Control: placebo } \\
\text { Duration of treatment/length of follow-up: mean = } 34 \text { months; standard deviation: } 12 \text { months } \\
\text { Planned: } 2 \text { years, decided on } 3 \text { years used for the primary analysis (after the results of the interim analysis suggested a } \\
\text { difference in effect) }\end{array}$} \\
\hline Outcomes & \multicolumn{2}{|c|}{$\begin{array}{l}\text { 1. Progression of cataract } \\
\text { 2. Logarithm of Minimum Angle of Resolution visual acuity } \\
\text { Outcomes were assessed approximately every } 4 \text { months } \\
\text { It is not clear whether outcome data were from the worse eye, or the average of both eyes }\end{array}$} \\
\hline Notes & \multicolumn{2}{|c|}{$\begin{array}{l}\text { Study period: } 1990 \text { to } 1995 \\
\text { Study population: apparently healthy people over } 40 \text { years with some degree of age-related cataract } \\
\text { Subgroup analysis: (a) type of cataract (b) severity of cataract (based on \% Pixels Opaque - Anterior) } \\
\text { Control group event rate: not applicable } \\
\text { Equivalence of baseline characteristics: those in the United Kingdom were slightly older, had lower serum proteins, poorer } \\
\text { liver function, lower vitamin levels, less brunescent lenses and more nuclear and cortical opacification } \\
\text { Quality of life indicators: none reported } \\
\text { Funding: Industry: Hoffmann-La Roche }\end{array}$} \\
\hline \multicolumn{3}{|l|}{ Risk of bias } \\
\hline Bias & Authors' judgement & Support for judgement \\
\hline $\begin{array}{l}\text { Random } \\
\text { sequence } \\
\text { generation } \\
\text { (selection bias) }\end{array}$ & Low risk & Efron's biased coin method \\
\hline $\begin{array}{l}\text { Allocation } \\
\text { concealment } \\
\text { (selection bias) }\end{array}$ & Low risk & $\begin{array}{l}\text { Those involved in preparing the randomization scheme were } \\
\text { oot associated with determining eligibility, administering the } \\
\text { ntervention or assessing the outcomes }\end{array}$ \\
\hline $\begin{array}{l}\text { Blinding } \\
\text { (performance } \\
\text { bias and } \\
\text { detection bias) } \\
\text { All outcomes }\end{array}$ & Low risk & $\begin{array}{l}\text { Participants, care providers and outcomes assessors were } \\
\text { nasked }\end{array}$ \\
\hline $\begin{array}{l}\text { Incomplete } \\
\text { outcome data } \\
\text { (attrition bias) } \\
\text { All outcomes }\end{array}$ & High risk & $\begin{array}{l}\text { Losses to follow-up were } 22 \% \text { after } 2 \text { years and } 47 \% \text { after } 3 \\
\text { years }\end{array}$ \\
\hline $\begin{array}{l}\text { Selective } \\
\text { reporting } \\
\text { (reporting bias) }\end{array}$ & Low risk & $\begin{array}{l}\text { Results were reported for outcomes described in the methods } \\
\text { section }\end{array}$ \\
\hline Other bias & Unclear risk & $\begin{array}{l}\text { Those in the United States were apparently healthier with less } \\
\text { nature cataracts at baseline }\end{array}$ \\
\hline \multicolumn{3}{|l|}{ VECAT 2004} \\
\hline Methods & \multicolumn{2}{|c|}{$\begin{array}{l}\text { Design: parallel-arm RCT } \\
\text { Method of randomization: using permuted blocks } \\
\text { Method of allocation concealment: the allocation list was stored at a remote site and medication was dispensed in identical } \\
\text { containers } \\
\text { Number randomized: } 1204 \\
\text { Exclusions after randomization: } 11 \\
\text { Number analyzed: vitamin } E=595 \text {, placebo }=598 \text {; completers: vitamin } E=443 \text {, placebo }=456 \\
\text { Masking: participants, care providers and outcomes assessors masked } \\
\text { Losses to follow-up: withdrawn: vitamin E: } 78 \text {, placebo: } 72 \text {; discontinued: vitamin E: } 74 \text {, placebo: } 70 \\
\text { Unit of analysis: individuals }\end{array}$} \\
\hline Participants & \multicolumn{2}{|c|}{$\begin{array}{l}\text { Country: Australia } \\
\text { Age: mean: } 65.67 \text { years; range: } 55 \text { to } 80 \text { years } \\
\text { Gender ( } \% \text { female): } 56 \% \\
\text { Inclusion criteria: age between } 55 \text { and } 80 \text { years } \\
\text { Exclusion criteria: prior cataract surgery, advance cataract in both eyes, glaucoma, known sensitivity to vitamin E, long- } \\
\text { term treatment with steroids and anti-coagulants }\end{array}$} \\
\hline Interventions & \multicolumn{2}{|l|}{$\begin{array}{l}\text { Treatment: } \\
\text { (a) Vitamin E, } 500 \text { IU natural vitamin E in soybean oil daily } \\
\text { Control: placebo } \\
\text { Duration of treatment/length of follow-up: } 4 \text { years }\end{array}$} \\
\hline
\end{tabular}




\begin{tabular}{|c|c|c|}
\hline Outcomes & \multicolumn{2}{|c|}{$\begin{array}{l}\text { 1. Incidence of cataract (nuclear, cortical and posterior subcapsular, clinical grading and digital assessment) over } 4 \text { years } \\
\text { 2. Cataract extraction over } 4 \text { years } \\
\text { 3. Progression of cataract (nuclear, cortical and posterior subcapsular, clinical grading and digital assessment) over } 4 \\
\text { years } \\
\text { Outcomes were assessed annually } \\
\text { Incidence and prevalence were assessed using data from the worse eye, but progression rates were not derived from the eye } \\
\text { with the most advanced cataract change at baseline }\end{array}$} \\
\hline Notes & \multicolumn{2}{|c|}{$\begin{array}{l}\text { Study period: } 1995 \text { to } 2000 \\
\text { Study population: apparently healthy people over } 55 \text { years with some degree of age-related cataract } \\
\text { Subgroup analysis: (a) type of cataract } \\
\text { Control group event rate: } 16.7 \% \text { over } 4 \text { years for incident cataract } \\
\text { Equivalence of baseline characteristics: the vitamin E group had a statistically significant greater number of cases of } \\
\text { cortical and any cataract at baseline. Other baseline characteristics } \\
\text { appear equally distributed } \\
\text { Quality of life indicators: assessed using health-related quality of life SF-36 and visual function } 14 \text { questionnaires. Data not } \\
\text { reported } \\
\text { Funding: National Health and Medical Research Council of Australia and other foundations }\end{array}$} \\
\hline \multicolumn{3}{|l|}{ Risk of bias } \\
\hline Bias & Authors' judgement & Support for judgement \\
\hline $\begin{array}{l}\text { Random } \\
\text { sequence } \\
\text { generation } \\
\text { (selection bias) }\end{array}$ & Low risk & $\begin{array}{l}\text { Randomization schedule was prepared by a biostatistician using } \\
\text { permuted blocks allocation scheme }\end{array}$ \\
\hline $\begin{array}{l}\text { Allocation } \\
\text { concealment } \\
\text { (selection bias) }\end{array}$ & Low risk & $\begin{array}{l}\text { The allocation list was stored at a remote site and medication } \\
\text { was dispensed in identical containers }\end{array}$ \\
\hline $\begin{array}{l}\text { Blinding } \\
\text { (performance } \\
\text { bias and } \\
\text { detection bias) } \\
\text { All outcomes }\end{array}$ & Low risk & $\begin{array}{l}\text { Participants, care providers and outcomes assessors were } \\
\text { masked }\end{array}$ \\
\hline $\begin{array}{l}\text { Incomplete } \\
\text { outcome data } \\
\text { (attrition bias) } \\
\text { All outcomes }\end{array}$ & Unclear risk & $\begin{array}{l}\text { Losses to follow-up were greater than } 23 \% \text {, but were roughly } \\
\text { balanced across treatment groups }\end{array}$ \\
\hline $\begin{array}{l}\text { Selective } \\
\text { reporting } \\
\text { (reporting bias) }\end{array}$ & Low risk & $\begin{array}{l}\text { Results were reported for outcomes described in the methods } \\
\text { section }\end{array}$ \\
\hline Other bias & Unclear risk & $\begin{array}{l}\text { The vitamin E group had a statistically significant greater } \\
\text { number of cases of cortical and any cataract at baseline and } \\
\text { these were excluded from the analysis for incidence of cataract }\end{array}$ \\
\hline \multicolumn{3}{|l|}{ WHS 2004/8 } \\
\hline Methods & \multicolumn{2}{|c|}{$\begin{array}{l}\text { Design: } 2 \times 2 \times 2 \text { factorial RCT } \\
\text { Method of randomization: computer-generated list of random numbers } \\
\text { Method of allocation concealment: study pills in the treatment arms were identical except for the active agent in the beta- } \\
\text { carotene group } \\
\text { Number randomized: } 39,876 \\
\text { Exclusions after randomization: } \\
\text { Beta-carotene component: } 3141 \text {; beta-carotene: } 1534 \text {; placebo: } 1607 \\
\text { Vitamin E component: } 2201 \text {; vitamin E: } 1137 \text {; placebo: } 1064 \\
\text { Number analyzed: } \\
\text { Beta-carotene component: } 36,735 \text {; beta-carotene: } 18,405 \text {; placebo: } 18,330 \\
\text { Vitamin E component: } 37,675 \text {; vitamin E: } 18,800 \text {; placebo: } 18,875 \\
\text { Masking: participants, care providers and outcome assessors masked } \\
\text { Losses to follow-up: the beta-carotene component was terminated early and for the vitamin E component, mortality and } \\
\text { morbidity follow-up were } 97.2 \% \text { and } 99.4 \% \text { respectively } \\
\text { Unit of analysis: individuals }\end{array}$} \\
\hline Participants & \multicolumn{2}{|c|}{$\begin{array}{l}\text { Country: USA } \\
\text { Age: mean: beta-carotene component: } 53.2 \text { years; vitamin E component: } 54.1 \text { years; range: } 45 \text { years and older } \\
\text { Gender: all female } \\
\text { Inclusion criteria: no history of cancer (except non melanoma skin cancer), coronary heart disease or cerebrovascular } \\
\text { disease } \\
\text { Exclusion criteria: see above }\end{array}$} \\
\hline Interventions & \multicolumn{2}{|l|}{ Treatment: } \\
\hline
\end{tabular}




\begin{tabular}{|c|c|c|}
\hline & \multicolumn{2}{|c|}{$\begin{array}{l}\text { (a) Beta-carotene, } 50 \mathrm{mg} \text { on alternate days } \\
\text { (b) Vitamin E: } 600 \mathrm{IU} \text { on alternate days } \\
\text { (c) Aspirin } 100 \mathrm{mg} \text { on alternate days } \\
\text { Control: placebo, aspirin, beta-carotene, vitamin E } \\
\text { Duration of treatment/length of follow-up: } \\
\text { Beta-carotene component: median: } 2.1 \text { years; range: } 0.00 \text { to } 2.72 \text { years } \\
\text { Vitamin E component: average: } 9.7 \text { years } \\
\text { Compliance: } \\
\text { Beta-carotene component: } 87 \% \text { reported taking at least } 2 / 3 \mathrm{rd} \text { of study capsules; vitamin E component: } 78.9 \% \text { reported } \\
\text { taking at least } 2 / 3 \mathrm{rd} \text { of study capsules at } 5 \text { years and } 71.6 \% \text { at } 10 \text { years }\end{array}$} \\
\hline Outcomes & \multicolumn{2}{|c|}{$\begin{array}{l}\text { 1. Incidence of age-related cataract } \\
\text { 2. Extraction of age related cataract } \\
\text { Outcomes were assessed every } 6 \text { months for first year and annually thereafter } \\
\text { Outcome assessment was based on self reports confirmed by medical record review } \\
\text { Outcome assessed in the worse eye is used in the analysis }\end{array}$} \\
\hline Notes & \multicolumn{2}{|c|}{$\begin{array}{l}\text { Study period: } 1993 \text { to } 2004 \\
\text { Study population: apparently health women health professionals } \\
\text { Subgroup analysis: } \\
\text { Beta-carotene component: (a) age, (b) baseline smoking status } \\
\text { Vitamin E component: (a) age, (b) type of cataract } \\
\text { Control group event rate: } \\
\text { Beta-carotene component: } 0.007 \% \text { over } 2.1 \text { years for incident cataract } \\
\text { Vitamin E component: } 6.5 \% \text { over } 9.7 \text { years for incident cataract } \\
\text { Equivalence of baseline characteristics: important baseline characteristics appear equally } \\
\text { distributed } \\
\text { Quality of life indicators: none reported } \\
\text { Funding: National Institutes of Health, USA }\end{array}$} \\
\hline \multicolumn{3}{|l|}{ Risk of bias } \\
\hline Bias & Authors' judgement & Support for judgement \\
\hline $\begin{array}{l}\text { Random } \\
\text { sequence } \\
\text { generation } \\
\text { (selection bias) }\end{array}$ & Low risk & Computer-generated list of random numbers \\
\hline $\begin{array}{l}\text { Allocation } \\
\text { concealment } \\
\text { (selection bias) }\end{array}$ & Low risk & $\begin{array}{l}\text { Study pills in the treatment arms were identical except for the } \\
\text { active agent in the beta-carotene group }\end{array}$ \\
\hline $\begin{array}{l}\text { Blinding } \\
\text { (performance } \\
\text { bias and } \\
\text { detection bias) } \\
\text { All outcomes }\end{array}$ & Low risk & $\begin{array}{l}\text { Participants, care providers and outcome assessors were } \\
\text { masked }\end{array}$ \\
\hline $\begin{array}{l}\text { Incomplete } \\
\text { outcome data } \\
\text { (attrition bias) } \\
\text { All outcomes }\end{array}$ & Low risk & $\begin{array}{l}\text { Morbidity follow-up rates for the beta-carotene and vitamin E } \\
\text { arms were } 99 \% \text { and } 97.2 \% \text { respectively }\end{array}$ \\
\hline $\begin{array}{l}\text { Selective } \\
\text { reporting } \\
\text { (reporting bias) }\end{array}$ & Low risk & $\begin{array}{l}\text { Results were reported for outcomes described in the methods } \\
\text { section }\end{array}$ \\
\hline Other bias & Low risk & Met other parameters of quality that were assessed (see text) \\
\hline
\end{tabular}

RCT: randomized controlled trial 
Characteristics of excluded studies [ordered by study ID]

\begin{tabular}{|c|c|}
\hline Study & Reason for exclusion \\
\hline AREDS 2000 & Article regarding zinc as the exposure in the AREDS study \\
\hline Asensio-Sanchez 2002 & Article in Spanish: letter regarding results for age-related macular degeneration in the AREDS study \\
\hline Augustin 2002 & Article in German: comment regarding the AREDS study \\
\hline CTNS 2008 & $\begin{array}{l}\text { The intervention is a multivitamin-mineral supplement CENTRUM. As it contains a combination of multiple } \\
\text { vitamins and minerals, it is not possible to tease out the effects of the major antioxidant vitamins: beta-carotene, } \\
\text { vitamin } C \text { and vitamin } E \text {, either singly or in combination, which is the focus of this review }\end{array}$ \\
\hline Diplock 1994 & Review on antioxidants and their role in disease prevention \\
\hline Floren 1994 & Review on the pathophysiology of antioxidants in relation to cataract \\
\hline Leske 1997 & Barbados Eye Study: not an RCT \\
\hline Li 1993 & Article in Chinese: reporting the preliminary results of the Linxian study \\
\hline LINXIAN 1993 & Though an RCT, the analysis was conducted in a non-random sample at the end of the trial \\
\hline Mares-Perlman 2000 & Beaver Dam Eye Study: not an RCT \\
\hline Olmedilla 2003 & Sample size of the study: 17; unit of analysis: eyes; high loss to follow-up after 1 year \\
\hline Phakan 1982 & Article in German: duration of treatment 9 months \\
\hline Sackett 2002 & Review on the results of the AREDS study \\
\hline Schutt 2002 & Article in German: discussion regarding recommendations based on the AREDS study \\
\hline Seddon 1994 & $\begin{array}{l}\text { Physicians' Health Study I (PHS I): the intervention examined in this report, multivitamin supplements, was not } \\
\text { randomly assigned }\end{array}$ \\
\hline Seth 1999 & Duration of intervention: 30 days \\
\hline Sharma 1989 & Average length of follow-up: 9 to 11 months in the study groups \\
\hline Shiriaeva 1987 & Article in Russian: Not an RCT \\
\hline SUVIMAX 1998 & Principal Investigator reported that 'eye' outcomes will not be analyzed \\
\hline Teikari 1997 & Article examining an end of trial random sample of participants in the ATBC study \\
\hline Zrenner 2001 & $\begin{array}{l}\text { Article in German: regarding status of recommendations regarding vitamin A in relation to hereditary retinal } \\
\text { degeneration }\end{array}$ \\
\hline
\end{tabular}

AREDS: Age-Related Eye Disease Study; ATBC: Alpha-tocopherol Beta-carotene Study; RCT: randomized controlled trial 
Characteristics of ongoing studies [ordered by study ID]

\begin{tabular}{|c|c|}
\hline \multicolumn{2}{|l|}{ NCT01142960 } \\
\hline Trial name or title & $\begin{array}{l}\text { Effects of vitamin C and Lycium barbarum supplements on the progression of senile cataract in Hong Kong Chinese } \\
\text { population }\end{array}$ \\
\hline Methods & Design: parallel assignment RCT \\
\hline Participants & $\begin{array}{l}\text { Country: Hong Kong, China } \\
\text { Age: } 60 \text { to } 75 \text { years } \\
\text { Gender: male and female } \\
\text { Inclusion criteria: unlikely to have cataract surgery within } 3 \text { years, present of mild to moderate cataract, no ocular } \\
\text { anomalies or use of ocular drugs } \\
\text { Exclusion criteria: diabetes mellitus, renal failure, use of anticoagulants, alcoholism, regular use of multivitamin, } \\
\text { mineral or other antioxidant supplements }\end{array}$ \\
\hline Interventions & $\begin{array}{l}\text { Treatment: vitamin C: } 500 \mathrm{mg} \text { daily } \\
\text { Control: placebo } \\
\text { Duration of treatment/length of follow-up: } 3 \text { years }\end{array}$ \\
\hline Outcomes & $\begin{array}{l}\text { 1. Lens opacity classification system III (LOCS III) } \\
\text { 2. Visual acuity }\end{array}$ \\
\hline Starting date & July 2010 \\
\hline Contact information & Chi-wai Do, PhD; socwdo@ @inet.polyu.edu.hk \\
\hline Notes & $\begin{array}{l}\text { Study population: apparently healthy between } 60 \text { and } 75 \text { years } \\
\text { Funding: the Hong Kong Polytechnic University }\end{array}$ \\
\hline \multicolumn{2}{|l|}{ WACS } \\
\hline Trial name or title & The Women's Antioxidant and Cardiovascular Study (WACS) \\
\hline Methods & $\begin{array}{l}\text { Design: } 2 \times 2 \times 2 \times \text { factorial RCT } \\
\text { Method of randomization: computer-generated list of random numbers } \\
\text { Method of allocation concealment: study pills in the treatment arms were identical } \\
\text { Number randomized: } 8171 \\
\text { Number analyzed: pending analysis } \\
\text { Masking: participants, care providers and outcomes assessors masked } \\
\text { Losses to follow-up: pending analysis } \\
\text { Unit of analysis: pending analysis }\end{array}$ \\
\hline Participants & $\begin{array}{l}\text { Country: USA } \\
\text { Age: mean: } 60.6 \text { years, standard deviation: } 8.8 \\
\text { Gender: all female } \\
\text { Inclusion criteria: } 40 \text { years or older, postmenopausal or had no intention of becoming pregnant, self reported history of } \\
\text { cardiovascular disease or had at least } 3 \text { cardiovascular risk factors } \\
\text { Exclusion criteria: self reported history of cancer (excluding non-melanoma skin cancer), serious non cardiovascular } \\
\text { illness, use of anticoagulants, unwilling to forgo antioxidant vitamin supplementation outside the trial }\end{array}$ \\
\hline Interventions & $\begin{array}{l}\text { Treatment: (a) beta-carotene: } 50 \mathrm{mg} \text { every other day; (b) vitamin C: } 500 \mathrm{mg} \text { daily; (c) vitamin E: } 600 \mathrm{IU} \text { every other day } \\
\text { Control: placebo } \\
\text { Duration of treatment/length of follow-up: } 9.4 \text { years, range: } 8.3 \text { to } 10.1 \text { years }\end{array}$ \\
\hline Outcomes & $\begin{array}{l}\text { 1. Incidence of cataract } \\
\text { 2. Incidence of cataract extraction } \\
\text { 3. Loss of visual acuity }\end{array}$ \\
\hline Starting date & 1995 \\
\hline Contact information & $\begin{array}{l}\text { Dr. JoAnn E. Manson MD DrPH } \\
900 \text { Commonwealth Avenue East } \\
\text { Boston MA 02215-1204 }\end{array}$ \\
\hline Notes & $\begin{array}{l}\text { Study period: } 1995 \text { to } 2005 \\
\text { Study population: women with at least } 3 \text { cardiovascular risk factors; secondary prevention trial component of the } \\
\text { Women's Health Study (WHS) } \\
\text { Funding: National Heart, Lung and Blood Institute }\end{array}$ \\
\hline
\end{tabular}

